Review

\title{
A Review about Microalgae Wastewater Treatment for Bioremediation and Biomass Production-A New Challenge for Europe
}

\author{
Eugenio Geremia $^{1}\left(\mathbb{D}\right.$, Maddalena Ripa $^{1, *(\mathbb{D})}$, Claudio Marcello Catone ${ }^{1}(\mathbb{D})$ and Sergio Ulgiati ${ }^{1,2}(\mathbb{D})$ \\ 1 Department of Science and Technology, Parthenope University of Naples, Isola C4, 80143 Naples, Italy; \\ geremia000@gmail.com (E.G.); claudiocatone92@libero.it (C.M.C.); sergio.ulgiati@uniparthenope.it (S.U.) \\ 2 School of Environment, Beijing Normal University, No. 19 Xinjiekouwai Street, Beijing 100875, China \\ * Correspondence: maddalena.ripa@gmail.com
}

Citation: Geremia, E.; Ripa, M.; Catone, C.M.; Ulgiati, S. A Review about Microalgae Wastewater Treatment for Bioremediation and Biomass Production-A New Challenge for Europe. Environments 2021, 8, 136. https://doi.org/ 10.3390 /environments 8120136

Academic Editor: Yu-Pin Lin

Received: 26 October 2021

Accepted: 6 December 2021

Published: 9 December 2021

Publisher's Note: MDPI stays neutral with regard to jurisdictional claims in published maps and institutional affiliations.

Copyright: (C) 2021 by the authors. Licensee MDPI, Basel, Switzerland. This article is an open access article distributed under the terms and conditions of the Creative Commons Attribution (CC BY) license (https:// creativecommons.org/licenses/by/ $4.0 /)$.

\begin{abstract}
Microalgae have received much attention in the last few years. Their use is being extended to different fields of application and technologies, such as food, animal feed, and production of valuable polymers. Additionally, there is interest in using microalgae for removal of nutrients from wastewater. Wastewater treatment with microalgae allows for a reduction in the main chemicals responsible for eutrophication (nitrogen and phosphate), the reduction of organic substrates (by decreasing parameters such as BOD and COD) and the removal of other substances such as heavy metals and pharmaceuticals. By selecting and reviewing 202 articles published in Scopus between 1992 and 2020, some aspects such as the feasibility of microalgae cultivation on wastewater and potential bioremediation have been investigated and evaluated. In this review, particular emphasis was placed on the different types of wastewaters on which the growth of microalgae is possible, the achievable bioremediation and the factors that make large-scale microalgae treatment feasible. The results indicated that the microalgae are able to grow on wastewater and carry out effective bioremediation. Furthermore, single-step treatment with mixotrophic microalgae could represent a valid alternative to conventional processes. The main bottlenecks are the large-scale feasibility and costs associated with biomass harvesting.
\end{abstract}

Keywords: microalgae; algae; urban wastewater; bioremediation; biomass production; microalgae treatment

\section{Introduction}

A growth in the global population has coincided with agricultural intensification, industrial development, and urbanization, leading to a sharp increase in waste production and environmental pollution [1,2]. Among the various problems faced by modern society is the need for effective and sustainable management of urban wastewater. Untreated wastewaters can lead to the eutrophication of aquatic environments and represent a serious threat to water bodies. It is therefore necessary to apply appropriate treatment plans for the abatement and removal of substances such as ammonia $\left(\mathrm{NH}_{4}{ }^{+}\right)$, nitrate $\left(\mathrm{NO}_{3}{ }^{-}\right)$and phosphate $\left(\mathrm{PO}_{4}{ }^{3-}\right)[1,3]$. It is estimated that nitrogen pollution costs to the European Union are between 70 and 320 billion EUR/year [4]. Therefore, it is necessary to recycle nutrients and recover water: these, if recycled, can be considered a resource rather than waste [5].

\subsection{State of the Art}

Each year, 450 billion $\mathrm{m}^{3}$ of water are consumed globally for industrial and domestic use. Domestic use contributes to $70 \%$ of this consumption, and the consequent wastewater was to be used as a substrate for microalgae growth, about 23.5 billion tons of oil could be generated [6]. In addition to energy purposes, this algal biomass could also be used in human or animal nutrition, and owing to the presence of high-value molecules in cosmetics [6]. 
In Europe, improvements to wastewater management started with Directive 91/271/EEC, which deals with protecting the environment from eutrophication by establishing processes for wastewater treatment [7]. This was followed by Directive 98/15/EC which established discharge limits for total nitrogen and phosphorus (98/15/EC). According to this directive, for plants with over 100,000 personal equivalents, the maximum concentration of total phosphorus that can be released into the environment is $1 \mathrm{mg} / \mathrm{L}$, while that of total nitrogen is $10 \mathrm{mg} / \mathrm{L}$ [8]. In the last 30-40 years, techniques for urban wastewater treatment have improved throughout most of Europe. In the 27 countries of the European Union, $69 \%$ of wastewater produced by the population undergoes tertiary treatment, while $13 \%$ undergoes only primary and secondary treatments. However, there are differences between the various European countries in the percentage of the population connected to urban wastewater treatment plants. Furthermore, a lack of data and the fact that not all of the population is connected to wastewater treatment plants does not allow for an exhaustive overall assessment [9]. Although wastewater treatment is a technology developed in the last century, some ancient civilizations around $4000 \mathrm{BC}$ already adopted rudimentary water treatment methods such as filtration through coal, exposure to light and use of boiling water [10]. Nowadays, conventional secondary treatments of wastewater based on biological purification with activated sludge from microorganisms such as bacteria have some disadvantages, such as high energy consumption (related to the nitrification-denitrification process), high operating costs and the need for sludge disposal [11-13]. Cocultivation of microalgae and bacteria may be a valid alternative to conventional wastewater treatment (WWT) [14-16]. Microalgae can grow in many environments and on different substrates such as wastewater. When growing on wastewater, microalgae assimilate phosphorus and nitrogen, nutrients necessary for their growth. In addition, they can also assimilate heavy metals and pharmaceutical products from wastewater and capture atmospheric carbon dioxide $\left(\mathrm{CO}_{2}\right)$. This, as well as favoring bioremediation of wastewater and protecting the environment from the risk of eutrophication, can also favor the removal of dangerous contaminants from wastewater and mitigate the negative effects caused by the excessive concentration of $\mathrm{CO}_{2}$ in the atmosphere. Lastly, this type of treatment, in addition to recycling water, can also produce microalgae biomass that can be destined for different uses, such as food, energy and other products at lower costs $[17,18]$. The use of microalgae for wastewater treatment dates back to the 1950s, when Oswald devised this type of treatment as an alternative to traditional waste-stabilization ponds (WSP) [19]. However, research on this field has only increased in the last decade $[20,21]$, also responding to an increasing global demand for microalgae, from 10.51 million tons in 2000 to 30.45 million tons in 2015. In 2016, the microalgae sector generated an added value of EUR 1.69 billion, and 14,000 workers were employed in the microalgae sector and associated production chain [22]. The major producers of algal biomass were Asian countries, which produced $97 \%$ of the total production in 2015. Europe is only the third largest producer, after USA. In Europe, production is still fluctuating, from 0.30 million tons in 2000 to 0.23 million tons in 2015. Norway, accounting for 65\%, was the largest European producer of microalgae biomass in 2015 [23]. Cultivation upon alternative culture media such as wastewater could further reduce algal production costs, ranging from 20 to $200 \mathrm{USD} / \mathrm{r} \mathrm{kg}$ depending on the case [24]. A large part of the production costs of microalgae (up to 20\%) are attributable to the use of industrial fertilizers used for their growth $[25,26]$. In this sense, cultivation upon wastewater could lead to both economic and environmental benefits.

\subsection{Goal of the Present Study}

This study performs a comprehensive evaluation of the literature on wastewater treatment with microalgae, biomass production and potential bioremediation of urban wastewater. It is organized according to the following points: (I) assessment of biomass growth on different types of urban wastewater, (II) assessment of using microalgae for wastewater bioremediation, (III) identification of advantages and disadvantages of the various types of microalgae treatment. Data relating to biomass production, productiv- 
ity, maximum specific growth rate, and bioremediation of different types of wastewater through the cultivation of microalgae within different conditions and using different technologies, were collected and compared, (see Tables S1-S5, provided as Supplementary Materials). Subsequently, Section 2 describes the methodology adopted for the analysis of publications, as well as the inclusion and exclusion criteria. Section 3 describes the potential of microalgae to grow on various types of wastewaters (raw, primary, secondary, and other substrates such as glycerol/glucose, centrate and secondary effluents from anaerobic digestion) as well as their bioremediation processes. In Section 4 the possible advantages and disadvantages of cultivation on wastewater are assessed. Moreover, the main bottlenecks that limit the cultivation of microalgae on an industrial scale are identified and discussed. Finally, Section 5 summarizes the main points of the study and possible future scenarios and limitations.

\section{Methods}

For the present review, a multistep approach has been developed, as shown in Figure 1. Scientific works were obtained from Scopus, the largest database of abstracts and citations of peer-reviewed literature. To obtain a systematic and in-depth review of the existing literature and a substantial set of data, several steps were followed. The first was a broad selection based on the choice of keywords. The terms "Microalgae" OR "Algae" AND "Urban wastewater" OR "Municipal wastewater" have been used. Research using these keywords resulted in 810 publications, including research articles, review articles, conference articles, book chapters and editorials. A subsequent refinement of the research was carried out through the implementation of the following criteria. First of all, a time interval of between 1992 and 2020 was selected. The other criteria used to refine the search were: (i) selection of research articles and reviews only; (ii) focus upon European countries only; (iii) selection of articles in English. The adoption of these criteria led to a final result of 202 publications, of which 193 were articles and eight were reviews. The choice of the time selection is motivated by the Europe Directive 91/271/EEC relating to the treatment of urban wastewater [7]. This directive aimed to protect the aquatic environment from the negative effects of urban wastewater discharges by establishing processes for collecting, treating and discharging of wastewater. As for the choice of the European geographical scale, this was motivated by the fact that Europe is investing heavily in sustainable growth and also in wastewater management, by promoting innovation. An example is the Horizon 2020 program which has invested almost EUR 80 billion over the last seven years in various projects, including many related to wastewater treatment such as the IDALG project [27] and the production of biomolecules with microalgae such as the Pro-Future project [28].

Figure 2 shows the temporal distribution of the 193 articles (the largest part of which was published in the last 10 years) and eight reviews. For the goals of the present review, a careful and detailed evaluation of these 202 selected publications was carried out. Furthermore, in order to address some specific aspects, a few additional publications in turn cited by the selected papers have also been taken into consideration.

On the basis of the evaluation of the 202 selected papers cited above, a further selection was carried out: 86 were considered deeply inherent to the topic, while 115 were considered only partially related to the present research or presenting insufficient data. The review was focused on objectives of the study, microalgae biomass production on different types of wastewaters, bioremediation of wastewater, comparison between different culture methods, different biomass-harvesting methods and relative advantages and disadvantages associated with them. Further, the limits of these processes and possible improvements to increase their efficiency have been identified. Some Tables (Tables S1-S5) based on these articles summarize the growth characteristics of microalgae on the different types of wastewaters (raw, primary, secondary and other substrates such as glycerol/glucose, centrate and secondary effluents from anaerobic digestion). In these Tables, the growth parameters of microalgae were expressed, such as biomass production $\left(\mathrm{g} \mathrm{L}^{-1}\right)$, maximum specific growth rate $\left(\mathrm{d}^{-1}\right.$ or $\left.\mathrm{h}^{-1}\right)$, productivities $\left(\mathrm{g} \mathrm{L}^{-1} \mathrm{~d}^{-1}\right.$ or $\left.\mathrm{g} \mathrm{m}^{-2} \mathrm{~d}^{-1}\right)$ and bioremedia- 
tion expressed as removal of chemical oxygen demand (COD), N and P. The classification is made on the basis of wastewaters, as these differ from each other. On the basis of this, wastewater is divided into (I) raw, containing suspended solids and, plastic, wood, paper, stones, etc. (Table S1); (II) primary wastewater, from which the suspended solids, oils and fats have been removed (Table S2); (III) secondary wastewater, where most of the organic substance is removed by biological purification with activated sludge from microorganisms such as bacteria that use the organic substance for their metabolic activity (Table S3); (IV) wastewater with other substrates such as glycerol and glucose or wastewaters of sludge line such as digestate anaerobic (an effluent deriving from the anaerobic digestion of sedimentation sludge) and centrate (supernatant of the digestate obtained by centrifugation) (Table S4); (V) generic wastewater, where the origin is not specified (Table S5). Each of these wastewaters undergoes different types of treatment: raw wastewater, through primary treatment (filtration, de-oiling, primary sedimentation), becomes primary wastewater. Primary wastewaters, through secondary treatment based on activated sludge and secondary sedimentation, become secondary wastewaters. Finally, secondary waters, through tertiary treatment (polishing, i.e., removal of nitrogen and phosphorus) can be rereleased into the environment (Figure 3).

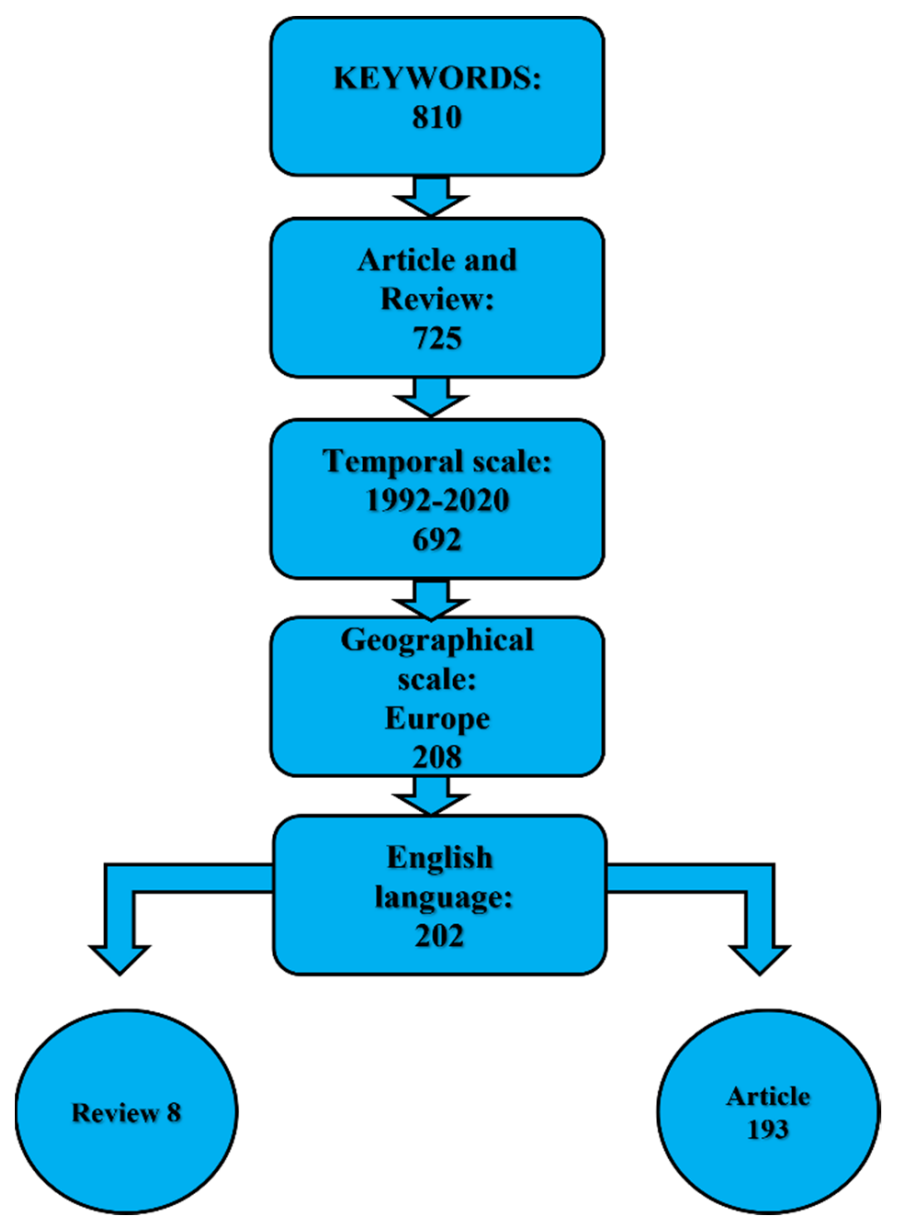

Figure 1. Flow diagram from literature research. 


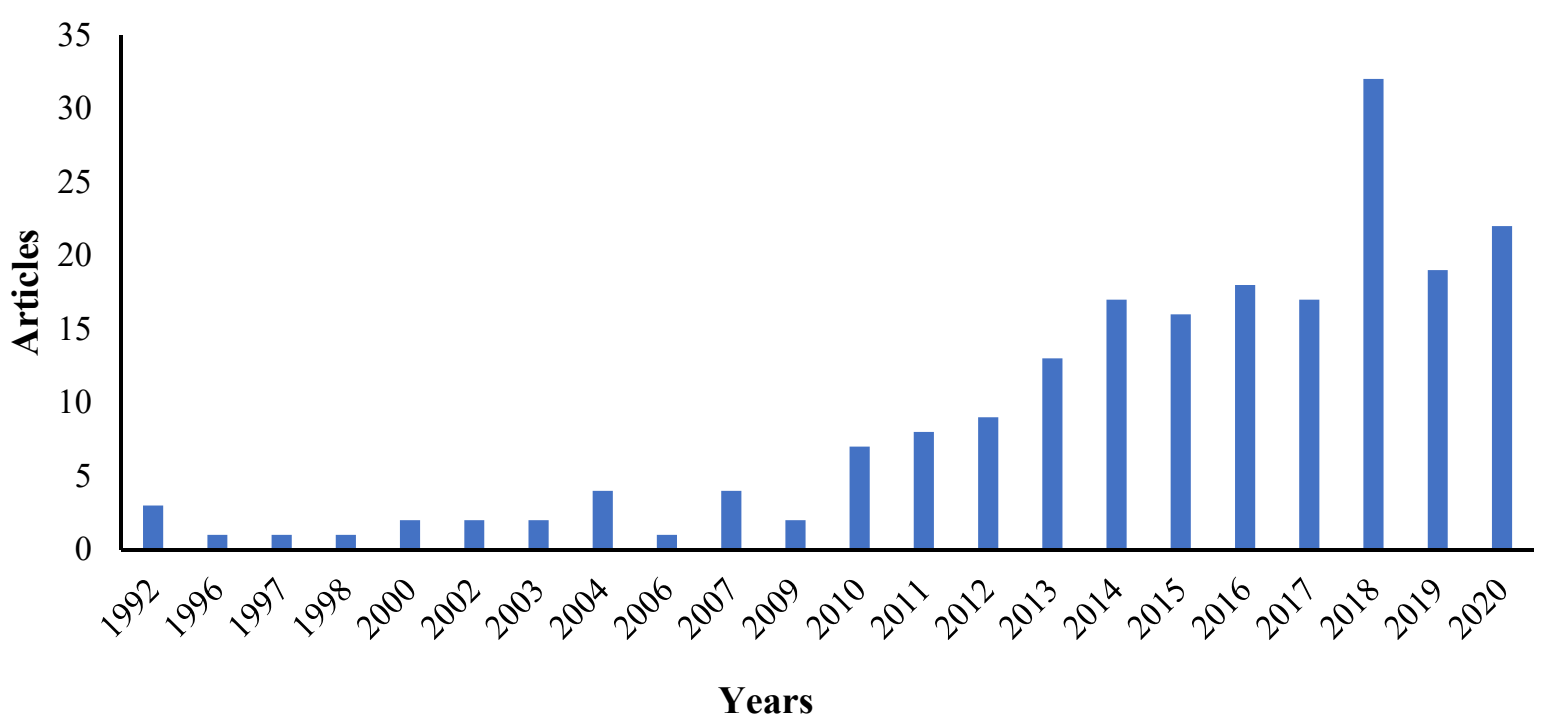

Figure 2. Temporal distribution of publications.

- Filtration

- De-oiling

- Primary sedimentation
- Activated sludge treatment

\section{- Secondary sedimentation}

- Polishing

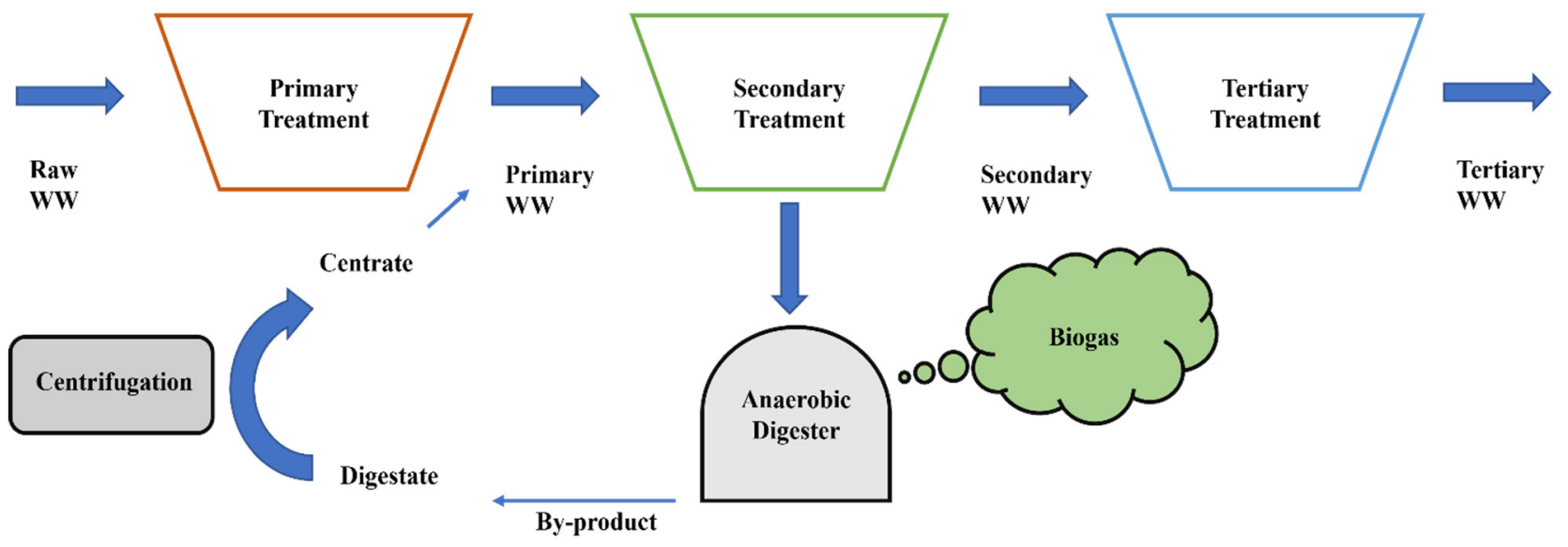

Figure 3. Different phases of wastewater treatment.

\section{Results}

As mentioned above, among the selected publications, eight review articles were also found, as summarized in Table 1.

From the consultation of the eight reviews, it was possible to set up the work. These made it possible to identify and investigate the fundamental aspects of the use of microalgae and cyanobacteria for the treatment of urban wastewater and production of microalgal biomass. Therefore, the aspects related to the technologies used, the different methods of cultivation, the microalgae suitable for growth on wastewater and the main types of wastewaters suitable for this purpose were investigated. Lastly, the strengths and bottlenecks that limit large-scale implementation of these process have been identified. In this work, the results of microalgal growth and bioremediation of wastewater were collected and compared. Finally, the different methods of cultivation of microalgae on wastewater, such as waste stabilization ponds systems (WPSs), High-Rate Algal Pond systems (HRAPs) and Photobioreactor system (PBRs), were examined and compared and summarized in the 
next subsections. The literature data relating to biomass production, expressed in $\mathrm{g} \mathrm{L}^{-1}$, volatile suspended solids (VSS) $\mathrm{g} \mathrm{L}^{-1}$ or suspended solids (SS) $\mathrm{g} \mathrm{L}^{-1}$; maximum specific growth rate, expressed in $\mathrm{d}^{-1}$ or $\mathrm{h}^{-1}$ and productivity, expressed in $\mathrm{g} \mathrm{L}^{-1} \mathrm{~d}^{-1}, \mathrm{~g} \mathrm{~m}^{-2} \mathrm{~d}^{-1}$,

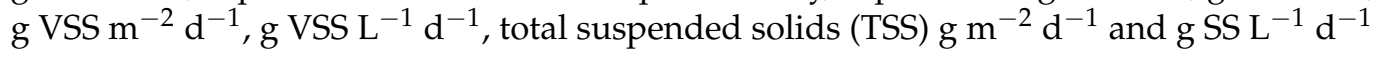
were identified and complied in Table S1 (for cultivation of microalgae on raw wastewater), Table S2 (primary wastewaters); Table S3 (secondary wastewaters); Table S4 (wastewaters mixed with other substrates) and Table S5 (nonspecified urban wastewaters).

Table 1. Outline of "Review" items regarding microalgae on wastewater.

\begin{tabular}{|c|c|c|c|c|c|}
\hline Item & Authors & Title & Main Topic & Source & Citations \\
\hline 1 & $\begin{array}{l}\text { Ho \& Goethals. } \\
\quad \text { (2020) [10] }\end{array}$ & $\begin{array}{c}\text { Municipal wastewater } \\
\text { treatment with pond } \\
\text { technology: Historical review } \\
\text { and future outlook. }\end{array}$ & $\begin{array}{l}\text { Historical and general } \\
\text { overview of pond } \\
\text { technology that treats } \\
\text { wastewater. Assessment of } \\
\text { future challenges. }\end{array}$ & $\begin{array}{l}\text { Ecological } \\
\text { Engineering }\end{array}$ & 5 \\
\hline 2 & $\begin{array}{l}\text { Arias et al. } \\
(2020)[20]\end{array}$ & $\begin{array}{l}\text { Production of polymers by } \\
\text { cyanobacteria grown in } \\
\text { wastewater: Current status, } \\
\text { challenges and future } \\
\text { perspectives. }\end{array}$ & $\begin{array}{l}\text { Ability of cyanobacteria to } \\
\text { grow in wastewater and the } \\
\text { capacity to produce } \\
\text { polymers from biomass. }\end{array}$ & $\begin{array}{c}\text { New } \\
\text { Biotechnology }\end{array}$ & 16 \\
\hline 3 & $\begin{array}{l}\text { Välitalo et al. } \\
\text { (2017) [29] }\end{array}$ & $\begin{array}{l}\text { Toxicological impacts of } \\
\text { antibiotics on aquatic } \\
\text { micro-organisms: A } \\
\text { mini review. }\end{array}$ & $\begin{array}{l}\text { Overview of antibiotics of } \\
\text { high ecotoxicological risk } \\
\text { for aquatic microorganisms. }\end{array}$ & $\begin{array}{l}\text { Hygiene and } \\
\text { Environmental } \\
\text { Health }\end{array}$ & 64 \\
\hline 4 & $\begin{array}{l}\text { Acién et al. } \\
\text { (2016) [30] }\end{array}$ & $\begin{array}{l}\text { Wastewater treatment using } \\
\text { microalgae: how realistic a } \\
\text { contribution might it be to } \\
\text { significant urban } \\
\text { wastewater treatment? }\end{array}$ & $\begin{array}{l}\text { Main bottlenecks that are } \\
\text { limiting the use of } \\
\text { microalgae on urban } \\
\text { wastewater. }\end{array}$ & $\begin{array}{c}\text { Applied } \\
\text { Microbiology and } \\
\text { Biotechnology }\end{array}$ & 85 \\
\hline 5 & $\begin{array}{l}\text { Whitton et al. } \\
\text { (2015) [31] }\end{array}$ & $\begin{array}{l}\text { Microalgae for municipal } \\
\text { wastewater nutrient } \\
\text { remediation: mechanisms, } \\
\text { reactors and outlook for } \\
\text { tertiary treatment. }\end{array}$ & $\begin{array}{l}\text { Technological challenges in } \\
\text { tertiary treatment with the } \\
\text { use of microalgae. }\end{array}$ & $\begin{array}{l}\text { Environmental } \\
\text { Technology }\end{array}$ & 61 \\
\hline 6 & $\begin{array}{l}\text { Hassard et al. } \\
\text { (2015) [32] }\end{array}$ & $\begin{array}{l}\text { Rotating biological contactors } \\
\text { for wastewater } \\
\text { treatment-A review. }\end{array}$ & $\begin{array}{l}\text { Developments of RBCs } \\
\text { (rotating biological } \\
\text { contactors) for wastewater } \\
\text { treatment. }\end{array}$ & $\begin{array}{l}\text { Process Safety and } \\
\text { Environmental } \\
\text { Protection }\end{array}$ & 53 \\
\hline 7 & $\begin{array}{l}\text { Singh \& Olsen. } \\
\text { (2011) [33] }\end{array}$ & $\begin{array}{c}\text { A critical review of } \\
\text { biochemical conversion, } \\
\text { sustainability and life cycle } \\
\text { assessment of algal biofuels. }\end{array}$ & $\begin{array}{l}\text { Advantages and } \\
\text { disadvantages of algal } \\
\text { biofuel production, } \\
\text { sustainability and life } \\
\text { cycle assessment. }\end{array}$ & Applied Energy & 275 \\
\hline 8 & Rizzo. (2011) [34] & $\begin{array}{c}\text { Bioassays as a tool for } \\
\text { evaluating advanced } \\
\text { oxidation processes in water } \\
\text { and wastewater treatment. }\end{array}$ & $\begin{array}{l}\text { Bioassays as a tool to } \\
\text { evaluate oxidation processes } \\
\text { in treating wastewater. }\end{array}$ & Water Research & 269 \\
\hline
\end{tabular}

\subsection{Microalgae Cultivation Technologies}

\subsubsection{Extensive Systems}

Waste stabilization ponds were the first large-scale wastewater treatment systems. They are shallow basins where the wastewater can be treated through the cocultivation of microalgae and bacteria, which contribute to the removal of nutrients ( $\mathrm{N}$ and $\mathrm{P}$ ) and COD, respectively [35]. WPS have several advantages such as simplicity and low cost to efficiently remove organic matter, pathogens and nutrients. The energy cost and the 
infrastructures for the wastewater treatment are not expensive [36]. On the other hand, this system presents bottlenecks such as the degree of wastewater purification obtained-this depends completely on the load rates of pollutants and on weather conditions, furthermore, this system is not easily controllable. These limits lead to low biological activity and odor problems, especially when climatic conditions are not optimal [35]. Finally, these systems have very long retention times and involve a lot of land availability, and for this reason they are used in rural areas due to the high availability of land [37].

\subsubsection{High-Rate Algal Pond Systems (HRAPs)}

High-Rate Algal Pond systems are a cost-effective technology for growing microalgae in wastewater. This technology dates back to the 1950s, and was developed in California by Oswald as an alternative to traditional WPS [21,38,39]. These channeled HRAPs have a low depth, and cultivation takes place outdoors using a mechanical shovel that contributes to the circulation of biomass and nutrients. HRAPs have many advantages, including reduced construction and maintenance costs, simple operation and lower energy consumption [24,40]. However, these ponds also have limitations such as poor light availability (resulting in poor productivity), possible contamination from other organisms and high evaporative losses of water [30,41]. Furthermore, non-negligible amounts of nitrogen (up to $73 \%$ ) in open systems may be lost due to ammonia stripping [41]. In spite of these disadvantages, HRAPs are widely used for microalgae cultivation around the world [24]. Although HRAPs have been studied and applied for several years, there are still gaps in the biological, physical and biochemical reactions that occur in microalgae-bacteria systems are less well-known than processes in conventional activated sludge processes [21].

\subsubsection{PBRs (Photobioreactors)}

Unlike HRAPs, closed systems such as PBRs have higher installation and operating costs but operate in controlled environments and result into better photosynthetic efficiency, which allows greater nutrient removal and more efficient biomass production [41]. However, the high operational cost of these systems make them unlikely to be used for sustainable wastewater treatment [37]. There are different types of PBRs, which exploit different types of technologies and are generally divided into horizontal and vertical. Vertical column PBRs hold great promise, as they require less surface area per unit volume thanks to their compactness and low manufacturing cost these ensure an optimal growth. PBRs allow adequate mixing of the cell suspension and promote the distribution of nutrients and gas exchange [42]. Menna [13] tested two different photobioreactors, bubble column photobioreactors (BCPBR) and photosequencing batch reactors (PSBER), to test the ability of microalgae to grow and remove nutrients from water. The former has many advantages during operation and maintenance compared to the other reactor. However, PSBRs are among the most widely used configurations for the implementation of microalgal consortia and offer the advantages of batch feeding and sequencing steps which are easy to implement and control [43]. Shi [44] tested a twin-layer photobioreactor prototype with Twin-Layer (TL) technology in order to evaluate the system's strengths and weaknesses in treating wastewater for biomass production and bioremediation. One of the main advantages is the ability to immobilize microalgae, resulting in greater ease of biomass harvesting. Finally, other models described in the literature include tubular photobioreactors, flat-panel and thin-layer reactors. Tubular flat-panel photobioreactors impose high energy consumption rates, and are generally ignored for this type of application [30].

\subsection{Cultivation on Different Effluents}

\subsubsection{Raw and Primary Wastewaters}

Generally, microalgae are used to reclaim the effluents of secondary treatments, using their autotrophic metabolism for growth and bioremediation through the absorption of $\mathrm{N}$ and $\mathrm{P}$ from the secondary wastewater. Furthermore, some of them can act also by assuming a mixotrophic or heterotrophic metabolism with the ability to consume organic 
substrates and reduce parameters such as COD and BOD (biochemical oxygen demand) in raw or primary wastewater $[1,30]$. Kotula [45] demonstrated that Chlorella sorokiniana can be used for the treatment of raw wastewater, obtaining a partial reduction in the main pollutants, as well as for the removal of organic micropollutants from wastewater. Batch experiments were initially conducted under autotrophic metabolism (constant light) and subsequently under mixotrophic metabolism ( $16 \mathrm{~h}$ of light $/ 8 \mathrm{~h}$ of dark) for seven days. The experiment in raw wastewater under autotrophic metabolism led to the growth of Chlorella sorokiniana to $0.169 \mathrm{~g} \mathrm{~L}^{-1}$ and a reduction in COD of $95 \%, \mathrm{~N} 62 \%$ and P $95 \%$. When mixotrophic metabolism was induced, a biomass concentration of $0.184 \mathrm{~g} \mathrm{~L}^{-1}$ and the COD, $\mathrm{N}$ and $\mathrm{P}$ removal efficiency of $89 \%, 76 \%$ and $93 \%$, were obtained, respectively (Table S1). Another method for treating primary or raw wastewater is the use of consortia between autotrophic microalgae and heterotrophic bacteria. Photosynthetic organisms are unable to assimilate the organic matter present in wastewater after primary treatment. Therefore, wastewater treatment with high COD using microalgae-based systems is often combined with anaerobic pretreatments or wastewater dilution. The use of heterotrophic bacteria (that consume oxygen and produce carbon dioxide) can become a very viable alternative in wastewater treatment $[10,12,24,46]$ Arashiro [47] evaluated nutrient removal and biomass growth in two HRAP, the first with primary wastewater (HRAP-PT) and the second with raw wastewater (HRAP-noPT). Considering the entire experimental period (260 days), the microalgal biomass in HRAP-PT was mainly composed of Chlorella sp., while in HRAP-noPT the predominant genus was Stigeoclonium sp. However, in the warm period the genus Chlorella sp. become the predominant genus, even in the untreated system. In addition to these organisms, other microorganisms such as diatoms and grazers have been identified in both systems, especially in the untreated system. The overall average productivity in the system with raw wastewater was $20 \pm 7 \mathrm{~g} \mathrm{VSS} \mathrm{m}^{2} \mathrm{~d}^{-1}$. This value was $30 \%$ higher than that obtained in the HRAP with the primary wastewater $\left(15 \pm 6 \mathrm{~g} \mathrm{VSS} / \mathrm{m}^{2} \mathrm{~d}\right)$. This possible increase in productivity in the system with raw wastewater can be attributed to the higher concentration of VSS in the influent. Indeed, the concentration of VSS in the influent was $49 \%$ higher in HRAP-noPT than in HRAP-PT. Additionally, regarding the removal of substances, there was no substantial difference in the different treatments. The COD removal efficiency was similar for both types of treatments, it was $62-65 \%$, and $\mathrm{P}$ and $\mathrm{N}$ were removed by $48-49 \%$ and $25-37 \%$, respectively, in HRAP-noPT and HRAP-PT (Tables S1 and S2). The microalgae and bacteria consortia can also be characterized by the use of microalgae with a mixotrophic or heterotrophic metabolism [48,49]. Ferro [48] tested the use of Chlorella vulgaris under mixotrophy and heterotrophy with the heterotrophic bacterium Rhizobium on synthetic raw wastewater (SRW) in batches for $96 \mathrm{~h}$. Under heterotrophic conditions, the final biomass was $0.19 \pm 0.01 \mathrm{~g} \mathrm{~L}^{-1}$, and the specific growth rate was $0.020 \pm 0.003 \mathrm{~h}^{-1}$ for the microalgae and $0.027 \pm 0.004 \mathrm{~h}^{-1}$ for the bacterium. Under these conditions, the nitrogen and phosphorus removal efficiency were, respectively, $(58.8 \pm 3.1) \%$ and $100 \%$. Under mixotrophic conditions, a higher biomass concentration $\left(0.85 \pm 0.01 \mathrm{~g} \mathrm{~L}^{-1}\right)$ was achieved, and a growth rate of $0.114 \pm 0.007 \mathrm{~h}^{-1}$ for microalgae was found and $0.079 \pm 0.001 \mathrm{~h}^{-1}$ for bacteria. The removal of nitrogen and phosphorus was $(55.9 \pm 0.4) \%$ and $100 \%$, respectively (Table S1). Ferro [17] addressed the problem of algae cultivation at high latitudes, where climatic adversity can be an obstacle for the growth of microalgae. They tested the growth of microalgae adapted to the Nordic climate in filtered but unsterilized primary wastewater. For the experiment, eight strains were tested, based on different characteristics such as Chlorella saccharophila or Chloroidium saccharophilum, Chlorella sorokiniana, Chlorella vulgaris, Coelastrella sp., Desmodesmus sp. (RUC-2), Desmodesmus sp. (2-6), Scenedesmus sp. and Scenedesmus obliquus (as a control strain). Subsequently, biomass production as well as nitrogen and phosphorus removal were evaluated after 13 days. Desmodesmus sp. (RUC-2) showed the highest growth rate $\left(1.18 \pm 0.11 \mathrm{~d}^{-1}\right)$, while Coelastrella sp. displayed the lowest $\left(0.58 \pm 0.21 \mathrm{~d}^{-1}\right)$ but with a larger cell size. Due to the size of the cell, the latter gave a higher biomass production $\left(1.46 \pm 0.16 \mathrm{~g} \mathrm{~L}^{-1}\right)$. Scenedemus obliquus and Scenedesmus sp. showed good biomass production (respectively 
$1.36 \pm 0.27 \mathrm{~g} \mathrm{~L}^{-1}$ and $\left.1.24 \pm 0.04 \mathrm{~g} \mathrm{~L}^{-1}\right)$. The lowest biomass concentration was found in Chlorella saccharophila, with a value of $0.80 \pm 0.08 \mathrm{~g} \mathrm{~L}^{-1}$. In addition to the production of biomass, the ability to reduce TN (total nitrogen) and P was also evaluated. All strains reduced the concentration of nitrogen and phosphate. Nitrogen was removed by $92-97 \%$ based on the strain, while phosphate was reduced almost or 100\% (Table S2).

\subsubsection{Secondary Wastewaters}

Microalgae are mainly applied for polishing as a tertiary treatment on secondary wastewater before discharge into water bodies. In tertiary treatment, $\mathrm{CO}_{2}$ plays an essential role in microalgae growth and $\mathrm{pH}$ control. Menna [13] tested the growth of Chlorella minutissima and Chlorella sp. in a batch mode and in continuous mode (BCPBR). The continuous phase lasted 50 days and was divided into three periods (I, II and III). In Period II, no $\mathrm{CO}_{2}$ was supplied and therefore no $\mathrm{pH}$ control was established, unlike the other two periods. In batch mode, cultivation took place until stationary growth was achieved, with biomass concentration $0.96 \mathrm{~g} \mathrm{SS} \mathrm{L}^{-1}$ and with a productivity of $0.10 \mathrm{~g} \mathrm{SS} \mathrm{L}^{-1} \mathrm{~d}^{-1}$. Subsequently, the cultivation took place in continuous mode: in Period I (217-385 h), the biomass concentration begins to constantly decrease until reaching $0.406 \pm 0.002 \mathrm{~g} \mathrm{SS} \mathrm{L}^{-1}$ and a volumetric productivity of $0.11 \mathrm{~g} \mathrm{~L}^{-1} \mathrm{~d}^{-1}$. In Period II (385-712 h, without $\mathrm{CO}_{2}$ supply), the biomass and volumetric productivity decreased to $0.226 \mathrm{~g} \mathrm{SS} \mathrm{L}^{-1}$ and $0.06 \mathrm{~g} \mathrm{SS} \mathrm{L}^{-1} \mathrm{~d}^{-1}$. Finally, in Period III ( $721 \mathrm{~h}$ to the end of the experiment), the concentration and productivity went back to $0.364 \mathrm{~g} \mathrm{SS} \mathrm{L}^{-1}$ and $0.10 \mathrm{~g} \mathrm{SS} \mathrm{L}^{-1} \mathrm{~d}^{-1}$. This study also tested removal of nitrogen and phosphorus; in Period I and III there was a complete removal of phosphorus and nitrogen. In Period II, there was a $98 \%$ removal of phosphorus and $59 \%$ of nitrogen. The halved capacity to absorb $\mathrm{N}$ is due to the lack of $\mathrm{CO}_{2}$ supply, which resulted in less nutrient uptake and consequently less growth. Additionally, Arbib [50] evaluated the growth of Chlorella vulgaris, Chlorella kesleri, Scenedesmus obliquus and natural bloom on secondary wastewater. Cultivation took place in batches for $240 \mathrm{~h}$ with $5 \% \mathrm{CO}_{2}$ in the air. The results showed greater growth by natural bloom and Scenedesmus obliquus, with $1.8 \pm 0.161$ and $1.6 \pm 0.105 \mathrm{~g} \mathrm{~L}^{-1}$, compared to Chlorella vulgaris and Chlorella kessleri with growth of $1.3 \pm 0.270$ and $1.1 \pm 0.110 \mathrm{~g} \mathrm{~L}^{-1}$, respectively. The greatest growth rate occurred in Scenedesmus obliquus $\left(0.672 \pm 0.168 \mathrm{~d}^{-1}\right)$, followed by Chlorella kessleri, natural bloom and Chlorella vulgaris $(0.624 \pm 0.168,0.600 \pm 0.144$ and $\left.0.480 \pm 0.144 \mathrm{~d}^{-1}\right)$. Nitrogen removal was greater than $90 \%$ in all crops, and phosphorus removal reached $98 \%$. The genus Chlorella sp. was also used in other experiments. Ruiz [3] evaluated growth and bioremediation in secondary wastewater and two enriched waters. The first was tested with the addition of sodium nitrate and potassium hydrogen phosphate $(\mathrm{WW}+\mathrm{NP})$, and the second with further addition of micronutrients $(\mathrm{WW}+\mathrm{NP}+\mathrm{M})$. The experiments were conducted in batches, and ended when growth stopped or when it was less than $1 \%$ per day. The NP-enriched wastewater showed the highest biomass concentration $\left(1.808 \pm 0.019 \mathrm{~g} \mathrm{SS} \mathrm{L}^{-1}\right)$. The WW without enrichment showed the lowest biomass concentration $\left(0.66 \pm 0.3015 \mathrm{~g} \mathrm{SS} \mathrm{L}^{-1}\right)$ but the highest growth rate, with a value of $0.83 \pm 0.09 \mathrm{~d}^{-1}$. The highest productivity was found in two enriched WW, with a productivity of $0.15 \mathrm{~g} \mathrm{SS} \mathrm{L}^{-1} \mathrm{~d}^{-1}$ for both. This shows that adding vitamins, minerals and metals to wastewater does not increase the growth rate of Chlorella vulgaris. This is due to the fact that urban wastewater effluents contain all the essential trace elements needed to grow Chlorella vulgaris, while phosphorus removal varied 80 to 96\%. Álvarez-Díaz [51] tested the growth of seven microalgae species under the same experimental conditions, evaluating the ability to grow in secondary wastewater in terms of biomass production and nutrient uptake for $600 \mathrm{~h}$ in batches. The microalgae tested are Chlorella vulgaris, Botryococcus braunii, Chlorella kessleri, Chlorella sorokiniana, Scenedesmus obliquus, Ankistrodesmus falcatu and Neochloris oleoabundans. Results showed that almost all microalgae can grow in wastewater, with an increase from the initial concentration of 0.02 to $0.17 \mathrm{~g} \mathrm{~L}^{-1}$. Neochloris oleoabundans showed a lower biomass concentration than the others $\left(0.25 \mathrm{~g} \mathrm{~L}^{-1}\right)$. Scenedesmus obliquus was the microalga that recorded the highest concentration compared to the others 
$\left(1.42 \mathrm{~g} \mathrm{~L}^{-1}\right)$. The highest growth rates were found in Chlorella kessleri $\left(1.59 \mathrm{~d}^{-1}\right)$, while the lowest was in Neochloris oleoabundans $\left(0.17 \mathrm{~d}^{-1}\right)$, as shown in Table S3. The latter also showed the lowest productivity $\left(0.008 \mathrm{~g} \mathrm{~L}^{-1} \mathrm{~d}^{-1}\right)$, unlike Chlorella vulgaris, which showed a productivity higher than $0.107 \mathrm{~g} \mathrm{~L}^{-1} \mathrm{~d}^{-1}$. Nutrient removal for nitrogen occurred in a range of 57 to $96 \%$, while phosphorus was fully assimilated in all crops.

3.2.3. Urban Wastewaters with Other Substrates: Glycerol/Glucose, Centrate and Secondary Effluents from Anaerobic Digestion

Microalgae can grow in different environments and in different experimental conditions. Recently the centrate has been used as a culture medium for biomass production. The centrate is the aqueous component of the digestate (by-product of the anaerobic digestion process) that has undergone centrifugation. This is reintroduced into the wastewater purification process, because it is impossible to return it to the environment due to its high nitrogen and phosphorus load [12,18,52]. Therefore, recycling of nutrients from the centrate could also be an economical and environmentally friendly option for growing biomass for a broad spectrum of byproducts. Peralta [18] tested the growth capacity of Chlorella fusca in three different concentrations of centrate: $33 \%$ centrate with distilled water, $66 \%$ centrate with distilled water and $100 \%$ centrate. The highest biomass concentration values were calculated when the stationary phase was reached: in the centrate at $33 \%$, this phase was reached on day 21 , with a value of biomass concentration close to $2 \mathrm{~g} \mathrm{~L}^{-1}$. The centrate at $66 \%$ reached the stationary phase on day 35 , with a biomass contraction of $2.5 \mathrm{~g} \mathrm{~L}^{-1}$, and finally, the highest biomass concentration was recorded at the centrate $100 \%$ again on day 35 , reaching a concentration of almost $3.5 \mathrm{~g} \mathrm{~L}^{-1}$. The $\mathrm{N}$ was removed completely in all treatments, while the best $\mathrm{P}$ reduction occurred in the centrate at concentration $66 \%$, with a removal efficiency of $75 \%$. In the centrate at 33 and $100 \%$, the removal efficiency was 53 and 48\%, respectively. Şirin \& Sillanpää [53] tested the growth of the marine microalga Nannochloropsis oculata on 100\% municipal wastewater and 70\% municipal wastewater $+30 \%$ seawater. The highest biomass concentration was reached in $100 \%$ municipal wastewater $\left(0.369 \mathrm{~g} \mathrm{~L}^{-1}\right)$, compared to that at $70 \%$ municipal wastewater $\left(0.345 \mathrm{~g} \mathrm{~L}^{-1}\right)$, while the growth rates were 0.45 and $0.42 \mathrm{~d}^{-1}$, respectively. The removal of $\mathrm{N}$ and $\mathrm{P}$ was also higher in growth on $100 \%$ of municipal wastewater. Caporgno [54] tested the growth of microalgae on primary wastewater and seawater diluted with centrate to reduce the total nitrogen concentration. In this way, the growth of microalgae at different TN was tested. The microalgae tested were Chlorella kessleri, Chlorella vulgaris on primary wastewater diluted with centrate at TN $=130 \mathrm{mg} \mathrm{N} / \mathrm{L}$ and Nannochloropsis oculata on seawater ( $25 \%$ of salinity) diluted with centrate at TN $=100 \mathrm{mg} \mathrm{N} / \mathrm{L}$ and. The freshwater species demonstrated the possibility of growing in urban wastewater, reaching high biomass production and nutrient removal. Both Chlorella strains reached high biomass dry weights ( $2.70 \pm 0.08 \mathrm{~g} \mathrm{~L}^{-1}$ and $2.91 \pm 0.02 \mathrm{~g} \mathrm{~L}^{-1}$, respectively). Nitrogen concentration reductions were around $96 \%$ and $95 \%$, and phosphorous concentration reductions were around $99 \%$ and $98 \%$, respectively. Nannochloropsis oculata gave a biomass concentration of $1.05 \pm 0.06 \mathrm{~g} \mathrm{~L}^{-1}$. The lower growth is due to a lower absorption of nutrients. In fact, the reduction efficiency of N (47\%) and P (96\%) was lower. Another perspective for the growth of microalgae on unconventional substrates is the growth on wastewater that uses glycerol as a carbon source. Nzayisenga [55] tested the growth of microalgae in wastewater under autotrophic conditions and in mixotrophic/heterotrophic conditions with the addition of glucose/glycerol for 8 days. The algal strain identified in urban wastewater corresponds phylogenetically very closely to Chlorella. The results show that the growth under autotrophy (wastewater only) gave a biomass concentration of $1.12 \mathrm{~g} \mathrm{~L}^{-1}$. The growth under conditions of mixotrophy with glycerol led to a biomass yield of $1.29 \mathrm{~g} \mathrm{~L}^{-1}$, while the one with glucose resulted in a biomass yield of $1.17 \mathrm{~g} \mathrm{~L}^{-1}$. Lastly, the growth under heterotrophy conditions with both glucose and glycerol produced a biomass concentration of $0.6-0.5 \mathrm{~g} \mathrm{~L}^{-1}$, respectively. The removal of $\mathrm{N}$ varied from a range of $76-89 \%$. Phosphorus removal was approximately $96 \%$ in all cultures. Anaerobic effluents from anaerobic digestion are also rich in substance; these contain higher nutrient concentrations 
than secondary wastewaters. Tao [56] tested the growth of Scenedesmus acuminatus and Chlorella vulgaris on anaerobic digestate municipal wastewater (ADMW) collected from a full-size mesophilic anaerobic digester that treated mixed municipal wastewater treatment sludge. Scenedesmus acuminatus gave a biomass concentration of $2.9 \mathrm{~g} \mathrm{~L}^{-1}$, while Chlorella vulgaris reached a biomass concentration of $2.0 \mathrm{~g} \mathrm{~L}^{-1}$. The removal of nitrogen and COD was almost similar for both. As for the phosphorus, Chlorella vulgaris assimilated only $24 \%$ of P, while Scenedesmus acuminatus 44\%. Hultberg [57] evaluated the removal of nutrients from the effluent of a moving bed biofilm reactor treated with microalgae consortium (Scenedesmus/Chlorella). The cultivation time of 3 to 5 days resulted in a large increase in biomass, from $0.233 \pm 0.04$ to $0.53 \pm 0.07 \mathrm{~g} \mathrm{~L}^{-1}$. The bioremediation in this case was very effective, especially regarding the removal of COD $(99 \%)$. These results are presented in Table S4.

\section{Discussion}

Wastewater bioremediation with microalgae was initially limited only to effluents from secondary treatment for polishing and removing substances such as nitrogen and phosphorus, responsible for the environmental problem of the eutrophication of water bodies $[31,58,59]$. Currently, the use of microalgae is also extending to other types of wastewaters for their bioremediation and production of microalgal biomass. Furthermore, in addition to tertiary treatment, these can also be used for the secondary treatment of wastewater through cocultivation with bacteria or the use of microalgae with mixotrophic metabolism. Besides microalgae, cyanobacteria can also be used for wastewater treatment $[20,60]$. However, for the process to be beneficial, it is crucial to identify the main factors that affect the growth of microalgae on wastewater.

\subsection{Microalgae Genera}

The genera of microalgae mainly found in the literature are the freshwater genera Scenedesmus, Chlorella and Desmodesmus. This is due to their ability to resist and grow on wastewater $[30,61]$. The use of microalgae for wastewater treatment has already been underway for several years in many countries such as the U.S.A, Mexico, Thailand, China, Australia [61,62], and now also in Europe [23]. Microalgae offer a solution to tertiary treatments thanks to their ability in absorption of $\mathrm{N}$ and $\mathrm{P}$ which they use for their growth. However, the use of marine microalgae for growth and bioremediation has also resulted in advantages, above all in the growth and production of lipids [26,54,63]. Schulze [64] tested the growth of euryhaline microalga Tetraselmis sp. CTP4 in urban wastewater both before and after the nitrification process. The results, summarized in Table S2, showed biomass growth and bioremediation of wastewater. Arbib [65] also tested the growth of the marine microalgae Chlorella stigmatofora in urban wastewater, with good results in bioremediation. Treatment with this microalga decreased the nitrogen and phosphorus values below the more restrictive levels established by the European regulation 98/1565/EC. Romero Villegas [26] evaluated the growth and bioremediation capacity of the marine microalga Nannochloropsis gaditana on the centrate diluted in sea water. In this study, excessive centrate concentrations led to a reduction in biomass productivity. This result is very different from the study tested by Peralta [18], which tested the growth of Chlorella fusca (freshwater microalgae) on $100 \%$ of a centrate, obtaining encouraging results. However, the centrate may contain high amounts of ammonium, which can be toxic if the threshold of $100-450 \mathrm{mg} / \mathrm{L}$ is exceeded $[63,66]$.

\subsection{Driving Forces in Wastewater Bioremediation by Microalgae}

One of the factors that influences the growth of microalgae on wastewater is certainly the availability of nutrients such as nitrogen and phosphorus. In addition to depending on substances such as nitrogen and phosphorus, the growth of microalgae depends above all on $\mathrm{CO}_{2}$. This can determine an increase in biomass production of about $30-50 \%[17,67]$, as it promotes the absorption of essential nutrients for the growth of microalgae $[4,13,68]$. 
In addition to being used as a source of inorganic carbon for the growth of microalgae, $\mathrm{CO}_{2}$ plays an essential role in maintaining the stability of $\mathrm{pH}$, a fundamental parameter for growth [69]. It has been widely demonstrated that the optimal $\mathrm{pH}$ for growth is around 8 , and that higher or lower values can negatively affect the metabolic activities of microorganisms $[67,68]$. However, it must be highlighted that the $\mathrm{CO}_{2}$ supply has very expensive operating costs for the process. In this regard, a valid alternative both from an economic and an environmental point of view is the so-called 'Industrial Symbiosis', namely the exchange of residues among processes that can become useful inflows to new production activities. Within such a framework, $\mathrm{CO}_{2}$ from flue gas of nearby power plants or industrial sites can be made available and recycled [70]. This would also further reduce the concentration of atmospheric $\mathrm{CO}_{2}$ responsible for global warming [10,20]. In addition to nutrients and $\mathrm{CO}_{2}$, light intensity also plays an essential role in the growth of microalgae. The availability of light is, indeed, essential for the growth of microalgae, when these grow in conditions of autotrophy. However, often the availability of light for microalgae can be influenced negatively by the presence of TSS in the wastewater. A high TSS load in wastewater can affect the penetration of light and cause shading. This induces a reduction in photosynthetic activity [46,71]. Climatic conditions are also crucial for the growth of microalgae. It has been widely documented how optimal climatic conditions of temperature, light intensity, frequency and photoperiod can positively influence productivity and nutrient removal, especially if open systems are dealt with $[17,41,72,73]$. Indeed, most species of microalgae are capable of carrying out photosynthesis and cell division over a wide temperature range, generally indicated as between 15 and $30^{\circ} \mathrm{C}$, but with optimal conditions between 20 and $25^{\circ} \mathrm{C}$ [74]. Below the optimal growth temperature, the increase in temperature has a positive effect on cell division and photosynthesis. On the other hand, an excessive temperature increase can determine heat stress that influences the enzymatic activity or modifies the proteins involved in the process and consequently determines an abrupt inhibition of growth [75]. Iasimone [76] demonstrated how the light intensity compared to the supply of nutrients determines a greater efficiency of growth, removal of substances and production of lipids, as shown in Table S1. The problem of the lack of light intensity characterizes the places where temperatures are rigid, such as those located in high latitudes [77]. Here, the cultivation of microalgae turns out to be very disadvantageous. In this case, it is more suitable to cultivate indigenous species that have a high degree of adaptation to climatic conditions and are more competitive, efficient and sustainable in situ $[17,78]$. The reliability of autochthonous crops compared to monospecific ones does not only concern harsh climates but can be extended to any type of cultivation [79]. However, when light is a limiting factor, it is possible to cultivate microalgae that have a heterotrophic metabolism and can grow using organic compounds such as glucose and glycerol as a source of carbon. Furthermore, microalgae with a mixotrophic metabolism are also very competitive. Glucose can be used as a carbon source, however, the disadvantage of its use is that it is very expensive. A valid and more sustainable alternative is the use of glycerol as an organic compound. Unlike glucose, glycerol is a byproduct of biodiesel production, and therefore has a very high and cheap availability. Nzayisenga [55] demonstrated how the Chlorella strain can grow under mixotrophic conditions using glycerol as a carbon source. This could allow the cultivation of microalgae and the treatment of wastewater, even in places where the availability of light is limited. However, not all strains are able to use glycerol as a carbon source under mixotrophic and heterotrophic conditions. It is therefore recommended to carry out further investigations on the effects of glycerol on microalgae growth and biomass production [80].

\subsection{Removal of Contaminants from Wastewater}

\subsubsection{Removal of N, P and COD}

Where bioremediation of wastewater is concerned, various treatments have been tested for the removal of substances such as nitrogen and especially phosphorus, to make remediation more efficient. As evidenced by the reviewed articles, microalgae are able 
to effectively uptake $\mathrm{N}$ and $\mathrm{P}$ from wastewater. The absorption range of nitrogen on the different types of wastewaters goes from $24 \%$ to $100 \%$, while that of phosphorus goes from $25 \%$ to $100 \%$. Furthermore, when microalgae are used for the treatment of raw or primary wastewater, they are also able to reduce COD in a percentage ranging from $23 \%$ to $95 \%$. Lavrinovičs [14] evaluated the removal of phosphorus in wastewater by cultivating the microalgae under phosphorus starvation before their use. The results showed that under this type of condition there was a greater removal of this substance from wastewater. However, this treatment process is problematic in large-scale applications.

\subsubsection{Removal of Heavy Metals, Xenobiotics and Pathogens}

In addition to the removal of these substances, microalgae can also remove heavy metals, xenobiotic substances and pathogens $[13,81]$. The development of the pharmaceutical industry in recent decades has led to an increase in pharmaceutical substances released into the environment. It has been reported that more than 200 substances are released into water bodies, mainly the antibiotic ciprofloxacin [82]. The most commonly seen drugs found in aquatic environments are nonsteroidal anti-inflammatory drugs (NSAIDs) such as ibuprofen and diclofenac, antibiotics (such as erythromycin, roxithromycin, ketoconazole, quinolones, fluoroquinolones), $\beta$-blockers (propranolol), antidepressants and antiepileptics (carbamazepine) [83]. Some studies have highlighted the ability of microalgae to remove these pharmaceutical products from wastewaters. Encarnação [84] evaluated the removal of acetaminophen (commonly known as paracetamol), ibuprofen and olanzapine by the microalga Nannochloropsis. The study demonstrated the ability of this microalgae to stay alive and to remove contaminants from water (with different efficiencies depending on the different concentrations). In addition to pharmaceuticals, microalgae can absorb heavy metals. Their efficiency is due to their large surface area and high binding affinity [85]. Chong [85] evaluated the ability of the microalgae Chlorella miniata and Scenedesmus quadricauda to remove heavy metals such as zinc and nickel from synthesized wastewater. Scenedesmus quadricauda showed the greatest bioremediation by reducing nickel and zinc by almost $99 \%$, Chlorella miniata drastically reduced the amount of nickel by $70 \%$. On the other hand, heavy metals are inhibitors of photosynthesis because they have the ability to block prosthetic metal atoms in the active sites of enzymes linked to photosynthesis [82]. In addition to these substances, pathogens can also be removed. Bellucci [86] highlighted how the use of microalgae can reduce the presence of pathogens such as Escherichia coli from wastewater, with results comparable to classic UV treatment.

\subsection{Secondary Treatment with Microalgae}

In addition to tertiary treatment, microalgae can sometimes also be used for secondary treatment of wastewaters. For example, microalgae with mixotrophic or heterotrophic metabolism could also be used for secondary wastewater treatments, due to their ability to absorb small organic molecules such as short-chain carbohydrates. This would result in a limited reduction in COD. Additionally, the cocultivation of microalgae with bacteria allows for secondary wastewater treatment by the removal of nutrients and organic matter, at reduced costs. These two approaches allow to carry out the treatment of wastewater with microalgae without sterilizing the wastewater [30], while avoiding the economic and energetic costs for the supply of oxygen $\left(\mathrm{O}_{2}\right)$ for bacteria and $\mathrm{CO}_{2}$ for microalgae [87-89].

\subsubsection{Secondary Treatment with Cocultivation Microalgae-Bacteria}

Typically, conventional processes for secondary treatment (activated sludge) take place through the remediation with microorganisms, generally heterotrophic bacteria and this process depends on $\mathrm{O}_{2}$. The microorganisms, in the presence of $\mathrm{O}_{2}$, carry out the biological oxidation of the organic substance [1,90], since oxygen allows nitrification by bacteria [91]. Generally, $\mathrm{O}_{2}$ is produced by electromechanical blowers with high energy intensity. This supply of $\mathrm{O}_{2}$ for wastewater treatment has high costs. It consumes approximately 1 to $3 \%$ of the total electricity generated in developed nations, of which 40 to $60 \%$ is expended 
on supplying air to the aeration basin. [58]. Since mechanical aeration causes up to $50 \%$ of the operating costs of wastewater treatment plant (WWTP). To solve this problem, the cocultivation of microalgae and bacteria could lead to economic and environmental benefits $[13,89,90]$. Obviously, the benefits are not always clear and effective when moving from laboratory prototypes to an industrial scale [19]. This synergy between the two microorganisms promotes both the growth of microalgae and bacteria. The latter remove COD through heterotrophic growth, producing $\mathrm{CO}_{2}$, and at the same time the microalgae assimilate $\mathrm{CO}_{2}$ and the nutrients generated by bacteria, converting these substances into algal cell material through photosynthesis and producing $\mathrm{O}_{2}$ that stimulates bacterial activity $[10,21,49]$. This type of interaction is not always successful because in some cases the microalgae do not release enough oxygen to the bacteria for the degradation of COD. This, if not completely eliminated, could stimulate the mixotrophic metabolism of microalgae, thus reducing the net availability of oxygen for bacteria [49]. Further advantages generated by this interaction are the exchange of cofactors such as growth-promoting compounds, vitamins, organic compounds and extracellular matrix. The latter provides attachment sites for bacteria and allows flocculation and subsequent harvesting of microalgal biomass. [24,49,59]. However, cocultivation may be limited by competition between microalgae and bacteria for nutrients. Bacteria can inhibit the growth of microalgae by modifying the culture broth and secreting toxins. Microalgae can also negatively affect bacteria by inhibiting or suppressing bacterial activity by increasing the $\mathrm{pH}[48,49,92]$.

\subsubsection{Secondary Treatment with Microalgae with Mixotrophic Metabolism}

Microalgae with mixotrophic metabolism could be used for secondary wastewater treatments. With this type of treatment, the microalgae are able to oxidize organic matter in wastewater and to assimilate the resulting $\mathrm{CO}_{2}$ for photosynthesis [82]. The classic WWT is a two-step process that involves high energy consumption related to the supply of $\mathrm{O}_{2}$ (for the oxidation of organic matter) and $\mathrm{CO}_{2}$ (for photosynthesis). The advantage of the treatment with mixotrophic metabolism microalgae over traditional WWT systems is the fact that it is able to obtain the N, P and C discharge standards with a single treatment, also avoiding the energy consumption related to the supply of $\mathrm{O}_{2}$ and $\mathrm{CO}_{2}[87,93]$. Generally, most of the studies concerning the WWT with microalgae are carried out with monospecific cultures on a laboratory scale in controlled environments. However, in large-scale outdoor cultivations microalgae are often contaminated with other microorganisms; this represents an important problem because it inhibits microalgae growth and lowers the quality of the bioproducts derived from them [94]. A possible solution to this problem is represented by the extremophilic red alga Galderia sulphuraria. This unicellular alga is able to live in acidic environments ( $\mathrm{pH}$ between 1-5). It is one of the most adapted eukaryotes to acidic conditions and is predominant in extreme conditions where it is difficult for other organisms to grow $[93,94]$. Further, Galdieria sulphuraria can grow both in autotrophy, mixotrophy and heterotrophy [95]. Finally, its efficacy in wastewater treatment is well-documented [96,97]. This ability makes it very versatile and suitable for the removal of organic carbon from wastewater in a single phase instead of the two-step classic treatment. Regarding energy consumption, as reported by Oswald [98], in the conventional activated sludge secondary treatment, the removal of $1 \mathrm{~kg}$ of BOD is associated with the consumption of $1 \mathrm{~kW} / \mathrm{h}$ for aeration and the emission of $1 \mathrm{~kg} \mathrm{CO} 2$ equivalent. On the contrary, $1 \mathrm{~kg}$ of BOD removed in a mixotrophic algal system does not require energy inputs, and in theory, the microalgae biomass obtained could anaerobically generate methane for $1 \mathrm{~kW} / \mathrm{h}$ of electricity. For all these reasons, large-scale treatment with mixotrophic metabolism microalgae could represent a valid solution, especially for lower energy consumption [88,89]. However, it remains crucial to identify the conditions that allow maximum oxidation of BOD coupled with photosynthetic $\mathrm{CO}_{2}$ fixation in order to maximize the net energy yields from wastewater treatment with microalgae with mixotrophic metabolism. 


\subsection{Potential Products Obtainable from Algal Biomass}

The advantage of wastewater treatment with microalgae is that, in addition to the bioremediation of the water, a microalgal biomass can be obtained that can be used for several purposes. Microalgal biomass is an interesting substrate for the production of energy or products with added value $[99,100]$. Regarding energy, there are many biofuels that can be produced by microalgal biomass, such as biodiesel, biogas, bioethanol and biohydrogen. One of the main products obtainable is certainly biodiesel, obtained through the extraction and conversion of lipids [101]. Biogas is produced through the anaerobic digestion of microalgal biomass $[70,102]$. Bioethanol is produced through the fermentation of the entire biomass or the remaining fraction of it, following the extraction of lipids for the production of biodiesel [33]. Another type of biofuel is biohydrogen $\left(\mathrm{bioH}_{2}\right)$. This is a renewable and nonpolluting energy source, because the combustion of $\mathrm{H}_{2}$ only releases water $\left(\mathrm{H}_{2} \mathrm{O}\right)$ as a byproduct [103]. In addition to the production of biofuels, microalgae can also be used for other purposes such as the production of high-value molecules, bioplastics, fertilizers and biochar. However, the use of biomass for these purposes requires further studies to verify its safety [26]. Microalgal biomass can be used for the production of highvalue molecules such as pigments including phycocyanin, carotenoids, etc., that can be used for the production of nutraceutical and cosmetic products $[25,104]$. Bioplastics are produced from polyhydroxybutarrate (PHB). This polymer, present in cyanobacteria such as Spirulina, has the chemical-physical characteristics of biocompatibility and biodegradability. PHB is a product of the assimilation of carbon from sources such as glucose, starch or $\mathrm{CO}_{2}$, and is used by microorganisms as a reserve material to be metabolized when other sources of energy are not available [105]. However, various studies indicate that the cost of producing bioplastics from cyanobacteria is still high [20]. Finally, microalgae can be used as fertilizer and biochar. The digestate produced by anaerobic digestion of microalgal biomass for the production of biogas can be used as a fertilizer [106]. Furthermore, the microalgae biomass, after being harvested and freeze-dried, can be used as an organic fertilizer (individually and mixed with vegetable compost) [107]. When microalgal biomass grown on wastewater does not present chemical and biological safety, it can be converted into another type of product such as biochar. This can be used as a soil amendment to improve the negative effects of drought and salt stress on plants, as it increases the water retention of the soil and improves its physical and biological properties [108].

\subsection{Main Bottlenecks and Future Perspectives}

Results highlight that the microalgae treatment (with different types of technologies applied) provides good bioremediation effect on all kinds of wastewater subjected to this type of treatment. However, whatever the type of treatment applied, there are several bottlenecks to overcome: (i) soil requirement for large-scale application, (ii) availability of light and (iii) biomass harvesting phase, which is influenced by different factors such as species, cell density and culture conditions.

\subsubsection{Soil Requirement}

In conventional systems of wastewater treatment, the need for land is not a problem, as an area of 1 ha can handle from 30,000 to 50,000 equivalent persons (p.e). Microalgae treatment would require a larger surface area for the same number of inhabitants-up to $30-50$ ha might be needed for the same treatment capacity. This limits the feasibility of such types of treatment on a large scale [30]. The real advantages of the microalgae treatment in HRAP are that this system is simpler and has a lower capital expenditures cost. In addition, maintenance is also simpler than conventional systems due to the lower demand for machinery and lower energy consumption (lower operating expenses). To reduce the land requirement problem, a possible solution could be the adoption of microalgae treatment in HRAP and elimination of the primary treatment from the entire wastewater treatment process [47]. Posadas et al. [109] in their theoretical study suggest that the removal of suspended solids is not necessary in a HRAP system since these can be 
biodegraded by microalgae through microalgae photosynthesis, which generates an excess of oxygenation in ponds. However, there are no data in the literature regarding primary wastewater treatment in HRAP with microalgae. Furthermore, the suspended solids in the raw wastewater can negatively influence the penetration of light into the water and inhibit the growth of microalgae, and consequently the success of the treatment.

\subsubsection{Availability of Light}

Light efficiency is essential for biomass growth. In open systems, sunlight is exploited for the growth of microalgae, this can represent an advantage both from an economic and environmental point of view. However, the open systems are exposed to seasonal variability, and this can lead to poor photosynthetic efficiency in converting solar energy into chemical energy and in a low productivity of biomass. Closed systems use constant artificial light, which leads to a higher productivity but ends up being very expensive from an energy and economic point of view, in so making its large-scale application much more difficult.

\subsubsection{Biomass Harvesting}

Harvesting appears to be the main bottleneck for large-scale microalgae cultivation. This process is estimated to contribute to $20-30 \%$ of the production costs $[1,30,110]$. Therefore, it is essential to choose efficient and less expensive harvesting methods. For this purpose, there are different mechanical processes such as centrifugation, sedimentation and filtration. Another mechanical treatment may be foam flotation. In this process, a gas is bubbled from the bottom, and this causes the biomass rises to the surface and its separation from the water through by foaming or filtration. Before this phase it is necessary to carry out coagulation and flocculation using inorganic, organic and chemical flocculants. After this process, the suspended cells are agglomerated and then sedimented. $[1,10,13]$. Flocculation consists of the aggregation of neutralized particles for the formation of flakes, while coagulation consists of neutralizing the negative surface charges of the microalgae [111]. The use of metal-based coagulants (aluminum sulfate or iron chloride) can make biomass useless in downstream processes [110]. Natural organic coagulants such as tanninor starch-based polymers can be a viable alternative [111]. The $\mathrm{pH}$ variation can induce self-flocculation $[13,53,112]$ but with a lower efficiency than traditional treatments [110]. It has been demonstrated that the use of classic flocculants is not economically feasible for production on an industrial scale $[10,13]$. A potential cost-effective alternative is bioflocculation via bridging or patching for cell-to-cell adhesion. This type of approach is based on the use of sticky polymeric exopolysaccharides (ESP) to form flakes that can improve the harvesting process [10]. Ubeda [113] tested the efficiency of exudates in the culture medium of Coelastrum pseudomicroporum, as a tool for harvesting algal biomass using flocculation assays and using Scenedesmus ellipsoideus as a target organism. This type of medium, used as a bioflocculant, appears to increase sedimentation rates and algae recovery with a yield of over $95 \%$. However, its effect was slower than classic treatments although more sustainable. An alternative strategy is to promote the dominance of fast-settling species by recycling the microalgae biomass harvested in the photobioreactor in order to increase the predominance of fast-settling microalgae species in HRAPs [114]. The use of coagulants and flocculants is therefore essential for the harvesting of suspended biomass. An alternative to improve harvesting may be the biofilm application (solid substrate). This has the ability to hold biomass, remove nutrients, and make harvesting more feasible than suspended systems. Furthermore, this type of application may not provide for system agitation and consequently lower energy consumption $[5,115,116]$. Biofilms are consortia of microalgae and bacteria trapped in a matrix in aquatic environments [117]. This system can work with short HRTs due to the biofilm's ability to retain and increase biomass, greater tolerance to local environmental changes and greater resistance to heavy metals. Furthermore, the biofilm can release extracellular polymeric substances (EPS) which can make up $70-95 \%$ of the weight of the biofilm. These EPS consist of the wastewater organic 
matter, metabolites formed during cell growth and substances released during lysis. EPS has the task of protecting cells from dehydration and improving resistance to toxins and antibiotics [115]. Biofilm cultivation occurs mainly in PBR. The advantages of this process are the immobilization of the biomass and the largest contact surface of microalgae with the wastewater, which improves the treatment process. Classic PBRs, although they can be reliable for biofilm formation, are energy intensive. An alternative to minimize costs would be to use a parallel plate reactor on unusable spaces such as house roofs. This type of PBR described by Zamalloa [5] can be treated as a "green roof", and can reduce the energy demand of the building. The substrate used for immobilization and cultivation with biofilm in photobioreactors are normally glass fibers, polyethylene, polytetrafluoroethylene PTFE, cellulosic sheets, polyurethane, polyvinyl, polystyrene, etc. However, these materials are expensive, synthetic and nonbiodegradable, and consequently potentially harmful to the environment. Garbowski [115] evaluated the feasibility of using pine bark as an alternative, biodegradable and low-cost material. The results demonstrated the effectiveness of using pine bark in the treatment of wastewater and in immobilizing algae on pine bark, facilitating its separation and then the harvesting of algal biomass. The biofilm is useful in retaining the algal biomass and preventing the cells from going into suspension. A limitation of this process is that biomass is still subject to hydrodynamic forces that can induce the leaching and detachment of material from the biofilm. A solution for this problem is the use of a double-layer photobioreactor (twin layer). Whit this type of PBR there is no loss of cells by leaching, and nutrients such as $\mathrm{N}$ and $\mathrm{P}$ can be removed from the wastewater [44]. Another alternative to improve harvesting and separate the liquid from the solid phase is to use membranes for biomass retention, allowing the decoupling of the BRT (biomass retention time) and the HRT. Separation acts as a harvesting process, with higher biomass concentration and nutrient reduction. The addition of ultrafiltration membranes may allow the recovery of water that can be reused for irrigation, urban and industrial use, by removing pathogens and suspended solids [46].

\section{Conclusions}

Microalgae can be grown on raw urban wastewater, treated urban wastewater and other wastewater such as digestate and centrate, deriving from the anaerobic digestion of activated sludge. However, the cultivation of microalgae on wastewater depends on several factors such as the selection of the species suitable for cultivation on wastewater, the type of wastewater, the technology used, the climatic factors (such as sunlight and temperature) and availability of $\mathrm{CO}_{2}$ that affects its yield. Through this approach, it is possible to obtain a production of microalgae biomass combined with the bioremediation of wastewater (mainly through the removal of substances such as nitrogen and phosphorus). This suggests that wastewater contains all the essential nutrients necessary for the cultivation and production of algal biomass, which can be used in different fields: (i) energy for the production of biofuels (biodiesel, biogas, biohydrogen, etc.), (ii) pharmaceutical products (derived from high-value biomolecules extracted from microalgae), (iii) foodstuffs (feed and food supplements), (iv) bioplastics and (v) chemicals (fertilizers and biochar). Microalgal biomass grown on wastewater is not yet completely safe, due to the possible presence of contaminants. However, it would be worthwhile to implement the knowledge and technologies in order to be able to allocate the microalgal biomass also to these purposes to expand their range of use. The use of microalgae provides a potential and valuable alternative to the conventional WWT, with the advantage of pursuing the goal of water treatment with less operational and energy costs and obtaining a resource such as microalgae biomass. A further advantage is associated with the fact that through this type of approach it is possible to use the $\mathrm{CO}_{2}$ released by other industrial plants for the cultivation of microalgae, subtracting such $\mathrm{CO}_{2}$ from emissions to the atmosphere. It should not be disregarded that this type of approach is representative of studies performed in the laboratory on a small scale, and the transition to a large-scale reality may present various obstacles such as high energy consumption and possible contamination 
by other microorganisms. A valid solution to this can be represented by the cultivation in mixotrophy of the extremophilic red alga Galdieria sulphuraria. The main bottlenecks that must be addressed are mainly the search for less expensive harvesting methods, both from an environmental and economic point of view, and the need for greater technological development of cultivation systems such as HRAP and PBR, in order to make the process feasible on large scale.

Supplementary Materials: The following are available online at https://www.mdpi.com/article/ 10.3390/environments8120136/s1, Table S1. Biomass production $\left(\mathrm{g} \mathrm{L}^{-1}\right)$, maximum specific growth rate $\left(\mathrm{d}^{-1}\right.$ or h$\left.^{-1}\right)$, productivities $\left(\mathrm{g} \mathrm{L}^{-1} \mathrm{~d}^{-1}\right.$ or $\mathrm{g} \mathrm{m}^{-2} \mathrm{~d}^{-1}$ ) and bioremediation expressed as removal of COD, $\mathrm{N}$ and $\mathrm{P}$ in the cultivation of microalgae on raw wastewater, Table S2. Biomass production $\left(\mathrm{g} \mathrm{L}^{-1}\right)$, maximum specific growth rate $\left(\mathrm{d}^{-1}\right)$, productivities $\left(\mathrm{g} \mathrm{L}^{-1} \mathrm{~d}^{-1}\right.$ or $\left.\mathrm{g} \mathrm{m}^{-2} \mathrm{~d}^{-1}\right)$ and bioremediation expressed as removal of $\mathrm{COD}, \mathrm{N}$ and $\mathrm{P}$ in the cultivation of microalgae on primary wastewater, Table S3. Biomass production $\left(\mathrm{g} \mathrm{L}^{-1}\right)$, maximum specific growth rate $\left(\mathrm{d}^{-1}\right)$, productivities $\left(\mathrm{g} \mathrm{L}^{-1} \mathrm{~d}^{-1}\right)$ and bioremediation expressed as removal of COD, $\mathrm{N}$ and $\mathrm{P}$ in the cultivation of microalgae on secondary wastewater, Table S4. Biomass production $\left(\mathrm{g} \mathrm{L}^{-1}\right)$, maximum specific growth rate $\left(\mathrm{d}^{-1}\right)$, productivities $\left(\mathrm{g} \mathrm{L}^{-1} \mathrm{~d}^{-1}\right)$ and bioremediation expressed as removal of COD, $\mathrm{N}$ and $\mathrm{P}$ in the cultivation of microalgae on wastewater with other substrates, Table S5. Biomass production $\left(\mathrm{g} \mathrm{L}^{-1}\right)$, maximum specific growth rate $\left(\mathrm{d}^{-1}\right)$, productivities and bioremediation expressed as removal of COD, $\mathrm{N}$ and $\mathrm{P}$ in the cultivation of microalgae on urban wastewater (not specified).

Author Contributions: E.G.: Data curation, Writing-Original draft preparation; M.R.: Conceptualization, Methodology, Data curation, Writing-Original draft preparation; C.M.C.: Writing-Reviewing and Editing; S.U.: Conceptualization, Writing-Reviewing and Editing, Funding acquisition. All authors have read and agreed to the published version of the manuscript.

Funding: This research was funded by: MAECI-Italian Ministry of Foreign Affairs and International Cooperation (Ministero degli Affari Esteri e della Cooperazione Internazionale-Direzione Generale per la Promozione del Sistema Paese; Grant number: PGR05278, China-Italy High Relevance project "Urban Circular Economy"). European Union, H2020-MSCA-ITN-2018 programme (Grant Number: 814247, ReTraCE Project), European Union, H2020-MSCA-RISE-2018 programme (Grant Number: 823967, ProCEedS project).

Acknowledgments: The authors gratefully acknowledge the support from the Italian Ministry of Foreign Affairs and International Cooperation (Ministero degli Affari Esteri e della Cooperazione Internazionale-Direzione Generale per la Promozione del Sistema Paese; Grant number: PGR05278, China-Italy High Relevance project "Urban Circular Economy"). The Authors also gratefully acknowledge the support from the projects "Realising the Transition towards the Circular Economy: Models, Methods and Applications (ReTraCE)", funded by the H2020-MSCA-ITN-2018 programme (Grant Number: 814247) and "Promoting Circular Economy in the Food Supply Chain (ProCEedS)", funded by the H2020-MSCA-RISE-2018 programme (Grant Number: 823967).

Conflicts of Interest: The authors declare no conflict of interest.

\section{Abbreviations}

$\begin{array}{ll}\text { ADMW } & \text { Anaerobic digestate municipal wastewater } \\ \mathrm{BioH}_{2} & \text { Biohydrogen } \\ \text { BOD } & \text { Biochemical oxygen demand } \\ \text { BPBR } & \text { Bubble column photobioreactors } \\ \text { BRT } & \text { Biomass retention time } \\ \mathrm{CO}_{2} & \text { Carbon dioxide } \\ \mathrm{COD} & \text { Chemical oxygen demand } \\ \text { ESP } & \text { Sticky polymeric exopolysaccharides } \\ \text { EPS } & \text { Extracellular polymeric substances } \\ \mathrm{H}_{2} & \text { Hydrogen } \\ \mathrm{H}_{2} \mathrm{O} & \text { Water }\end{array}$




$\begin{array}{ll}\text { HRAP } & \text { High-rate algal pond systems } \\ \text { HRAP-noPT } & \text { Algal ponds without primary treatment } \\ \text { HRAP-PT } & \text { Algal ponds with primary treatment } \\ \text { HRTs } & \text { Hydraulic retention time } \\ \mathrm{N} & \text { Nitrogen } \\ \mathrm{NH}_{4}{ }^{+} & \text {Ammonia } \\ \mathrm{NO}_{3} & \text { Nitrates } \\ \mathrm{NSAIDs} & \text { Nonsteroidal anti-inflammatory drugs } \\ \mathrm{O}_{2} & \text { Oxygen } \\ \mathrm{P} & \text { Phosporus } \\ \text { PBR } & \text { Photobioreactor } \\ \text { PHB } & \text { Polyhydroxybutarrate } \\ \text { PO }{ }_{4}{ }^{3-} & \text { Phosphates } \\ \text { PSBR } & \text { Photosequencing batch reactors } \\ \text { PTFE } & \text { Polytetrafluoroethylene } \\ \text { RBCs } & \text { Rotating biological contactors } \\ \text { SBR } & \text { Sequence Batch Reactor } \\ \text { SS } & \text { Suspended solids } \\ \text { SWW } & \text { Synthetic wastewater } \\ \text { TSS } & \text { Total suspended solids } \\ \text { TL } & \text { Twin-Layer } \\ \text { VSS } & \text { Volatile suspended solids } \\ \text { WSP } & \text { Waste stabilization ponds } \\ & \end{array}$

\section{References}

1. Lima, S.; Villanova, V.; Grisafi, F.; Caputo, G.; Brucato, A.; Scargiali, F. Autochthonous microalgae grown in municipal wastewaters as a tool for effectively removing nitrogen and phosphorous. J. Water Process Eng. 2020, 38, 101647. [CrossRef]

2. Paddock, M.B. Microalgae Wastewater Treatment: A Brief History. Preprints 2019, 2019120377. [CrossRef]

3. Ruiz, J.; Arbib, Z.; Álvarez-Díaz, P.D.; Garrido-Pérez, C.; Barragán, J.; Perales, J.A. Photobiotreatment model (PhBT): A kinetic model for microalgae biomass growth and nutrient removal in wastewater. Environ. Technol. 2013, 34, 979-991. [CrossRef] [PubMed]

4. Gentili, F.G. Microalgal biomass and lipid production in mixed municipal, dairy, pulp and paper wastewater together with added flue gases. Bioresour. Technol. 2014, 169, 27-32. [CrossRef] [PubMed]

5. Zamalloa, C.; Boon, N.; Verstraete, W. Decentralized two-stage sewage treatment by chemical-biological flocculation combined with microalgae biofilm for nutrient immobilization in a roof installed parallel plate reactor. Bioresour. Technol. 2013, 130, 152-160. [CrossRef]

6. Abinandan, S.; Shanthakumar, S. Challenges and opportunities in application of microalgae (Chlorophyta) for wastewater treatment: A review. Renew. Sustain. Energy Rev. 2015, 52, 123-132. [CrossRef]

7. European Commission. European Commission Directive 91/271/EEC on Urban Wastewater Treatment. 1991. Available online: https:/ / eur-lex.europa.eu/legal-content/EN/TXT/?uri=CELEX:31991L0271 (accessed on 9 July 2021).

8. Commission Directive 98/15/EC of 27 February 1998 Amending Council Directive 91/271/EEC with Respect to Certain Requirements Established in Annex I thereof (Text with EEA Relevance)—Publications Office of the EU. Available online: https: / / op.europa.eu/en/publication-detail/-/publication/ff7ec087-8cc3-4619-bffc-b08ea4883d2c (accessed on 16 November 2021).

9. Urban Waste Water Treatment in Europe-European Environment Agency. Available online: https://www.eea.europa. eu/data-and-maps/indicators/urban-waste-water-treatment/urban-waste-water-treatment-assessment-5 (accessed on 9 November 2020).

10. Ho, L.; Goethals, P.L.M. Municipal wastewater treatment with pond technology: Historical review and future outlook. Ecol. Eng. 2020, 148, 105791. [CrossRef]

11. Petrini, S.; Foladori, P.; Donati, L.; Andreottola, G. Comprehensive respirometric approach to assess photosynthetic, heterotrophic and nitrifying activity in microalgal-bacterial consortia treating real municipal wastewater. Biochem. Eng. J. 2020, 161, 107697. [CrossRef]

12. Mantovani, M.; Marazzi, F.; Fornaroli, R.; Bellucci, M.; Ficara, E.; Mezzanotte, V. Outdoor pilot-scale raceway as a microalgaebacteria sidestream treatment in a WWTP. Sci. Total Environ. 2020, 710, 135583. [CrossRef]

13. Mennaa, F.Z.; Arbib, Z.; Perales, J.A. Urban wastewater photobiotreatment with microalgae in a continuously operated photobioreactor: Growth, nutrient removal kinetics and biomass coagulation-flocculation. Environ. Technol. 2019, 40, 342-355. [CrossRef] [PubMed] 
14. Lavrinovičs, A.; Mežule, L.; Juhna, T. Microalgae starvation for enhanced phosphorus uptake from municipal wastewater. Algal Res. 2020, 52, 102090. [CrossRef]

15. Ruiz, J.; Álvarez-Díaz, P.D.; Arbib, Z.; Garrido-Pérez, C.; Barragán, J.; Perales, J.A. Performance of a flat panel reactor in the continuous culture of microalgae in urban wastewater: Prediction from a batch experiment. Bioresour. Technol. 2013, 127, 456-463. [CrossRef] [PubMed]

16. Miksch, K.; Cema, G.; Corvini, P.F.-X.; Felis, E.; Sochacki, A.; Surmacz-Górska, J.; Wiszniowski, J.; Zabczynski, S. R\&D priorities in the field of sustainable remediation and purification of agro-industrial and municipal wastewater. New Biotechnol. 2015, 32, 128-132. [CrossRef]

17. Ferro, L.; Gorzsás, A.; Gentili, F.G.; Funk, C. Subarctic microalgal strains treat wastewater and produce biomass at low temperature and short photoperiod. Algal Res. 2018, 35, 160-167. [CrossRef]

18. Peralta, E.; Jerez, C.G.; Figueroa, F.L. Centrate grown Chlorella fusca (Chlorophyta): Potential for biomass production and centrate bioremediation. Algal Res. 2019, 39, 101458. [CrossRef]

19. Sforza, E.; Ramos-Tercero, E.A.; Gris, B.; Bettin, F.; Milani, A.; Bertucco, A. Integration of Chlorella protothecoides production in wastewater treatment plant: From lab measurements to process design. Algal Res. 2014, 6, 223-233. [CrossRef]

20. Arias, D.M.; García, J.; Uggetti, E. Production of polymers by cyanobacteria grown in wastewater: Current status, challenges and future perspectives. New Biotechnol. 2020, 55, 46-57. [CrossRef] [PubMed]

21. Solimeno, A.; García, J. Microalgae and bacteria dynamics in high rate algal ponds based on modelling results: Long-term application of BIO_ALGAE model. Sci. Total Environ. 2019, 650, 1818-1831. [CrossRef] [PubMed]

22. Bussa, M.; Zollfrank, C.; Röder, H. Life-cycle assessment and geospatial analysis of integrating microalgae cultivation into a regional economy. J. Clean. Prod. 2020, 243, 118630. [CrossRef]

23. Biomass Production, Supply, Uses and Flows in the European Union: First Results from an Integrated Assessment I EU Science Hub. Available online: https:/ / ec.europa.eu/jrc/en/publication/eur-scientific-and-technical-research-reports/biomassproduction-supply-uses-and-flows-european-union-first-results-integrated-assessment (accessed on 16 January 2021).

24. Robles, Á.; Capson-Tojo, G.; Galès, A.; Ruano, M.V.; Sialve, B.; Ferrer, J.; Steyer, J.-P. Microalgae-bacteria consortia in high-rate ponds for treating urban wastewater: Elucidating the key state indicators under dynamic conditions. J. Environ. Manag. 2020, 261, 110244. [CrossRef] [PubMed]

25. Delrue, F.; Álvarez-Díaz, P.D.; Fon-Sing, S.; Fleury, G.; Sassi, J.-F. The environmental biorefinery: Using microalgae to remediate wastewater, a win-win paradigm. Energies 2016, 9, 132. [CrossRef]

26. Romero Villegas, G.I.; Fiamengo, M.; Acién Fernández, F.G.; Molina Grima, E. Outdoor production of microalgae biomass at pilot-scale in seawater using centrate as the nutrient source. Algal Res. 2017, 25, 538-548. [CrossRef]

27. Development of an Innovative Algae Based Tertiary Wastewater Treatment and Value Recovery System/INDALG Project I H2020 I CORDIS I European Commission. Available online: https:/ / cordis.europa.eu/project/id/733718 (accessed on 1 August 2021).

28. Microalgae Protein Ingredients for the Food and Feed of the Future I Profuture Project | H2020 | CORDIS | European Commission. Available online: https:/ / cordis.europa.eu/project/id/862980 (accessed on 1 August 2021).

29. Välitalo, P.; Kruglova, A.; Mikola, A.; Vahala, R. Toxicological impacts of antibiotics on aquatic micro-organisms: A mini-review. Int. J. Hyg. Environ. Health 2017, 220, 558-569. [CrossRef]

30. Acién, F.G.; Gómez-Serrano, C.; Morales-Amaral, M.M.; Fernández-Sevilla, J.M.; Molina-Grima, E. Wastewater treatment using microalgae: How realistic a contribution might it be to significant urban wastewater treatment? Appl. Microbiol. Biotechnol. 2016, 100, 9013-9022. [CrossRef]

31. Whitton, R.; Ometto, F.; Pidou, M.; Jarvis, P.; Villa, R.; Jefferson, B. Microalgae for municipal wastewater nutrient remediation: Mechanisms, reactors and outlook for tertiary treatment. Environ. Technol. Rev. 2015, 4, 133-148. [CrossRef]

32. Hassard, F.; Biddle, J.; Cartmell, E.; Jefferson, B.; Tyrrel, S.; Stephenson, T. Rotating biological contactors for wastewater treatment-A review. Process Saf. Environ. Prot. 2015, 94, 285-306. [CrossRef]

33. Singh, A.; Olsen, S.I. A critical review of biochemical conversion, sustainability and life cycle assessment of algal biofuels. Appl. Energy 2011, 88, 3548-3555. [CrossRef]

34. Rizzo, L. Bioassays as a tool for evaluating advanced oxidation processes in water and wastewater treatment. Water Res. 2011, 45, 4311-4340. [CrossRef]

35. Faleschini, M.; Esteves, J.L.; Camargo Valero, M.A. The Effects of Hydraulic and Organic Loadings on the Performance of a Full-Scale Facultative Pond in a Temperate Climate Region (Argentine Patagonia). Water Air Soil Pollut. 2011, 223, $2483-2493$. [CrossRef]

36. Butler, E.; Hung, Y.-T.; Suleiman Al Ahmad, M.; Yeh, R.Y.-L.; Liu, R.L.-H.; Fu, Y.-P. Oxidation pond for municipal wastewater treatment. Appl. Water Sci. 2015, 7, 31-51. [CrossRef]

37. González-Camejo, J.; Ferrer, J.; Seco, A.; Barat, R. Outdoor microalgae-based urban wastewater treatment: Recent advances, applications, and future perspectives. Wiley Interdiscip. Rev. Water 2021, 8, e1518. [CrossRef]

38. Ramos Tercero, E.A.; Sforza, E.; Morandini, M.; Bertucco, A. Cultivation of Chlorella protothecoides with urban wastewater in continuous photobioreactor: Biomass productivity and nutrient removal. Appl. Biochem. Biotechnol. 2014, 172, 1470-1485. [CrossRef] [PubMed] 
39. Thorin, E.; Olsson, J.; Schwede, S.; Nehrenheim, E. Co-digestion of sewage sludge and microalgae-Biogas production investigations. Appl. Energy 2018, 227, 64-72. [CrossRef]

40. Arbib, Z.; Ruiz, J.; álvarez-Díaz, P.; Garrido-Pérez, C.; Barragan, J.; Perales, J.A. Long term outdoor operation of a tubular airlift pilot photobioreactor and a high rate algal pond as tertiary treatment of urban wastewater. Ecol. Eng. 2013, 52, 143-153. [CrossRef]

41. González-Camejo, J.; Viruela, A.; Ruano, M.V.; Barat, R.; Seco, A.; Ferrer, J. Effect of light intensity, light duration and photoperiods in the performance of an outdoor photobioreactor for urban wastewater treatment. Algal Res. 2019, 40, 101511. [CrossRef]

42. Doria, E.; Longoni, P.; Scibilia, L.; Iazzi, N.; Cella, R.; Nielsen, E. Isolation and characterization of a Scenedesmus acutus strain to be used for bioremediation of urban wastewater. J. Appl. Phycol. 2012, 24, 375-383. [CrossRef]

43. Foladori, P.; Petrini, S.; Andreottola, G. Evolution of real municipal wastewater treatment in photobioreactors and microalgaebacteria consortia using real-time parameters. Chem. Eng. J. 2018, 345, 507-516. [CrossRef]

44. Shi, J.; Podola, B.; Melkonian, M. Application of a prototype-scale twin-layer photobioreactor for effective N and P removal from different process stages of municipal wastewater by immobilized microalgae. Bioresour. Technol. 2014, 154, 260-266. [CrossRef]

45. Kotoula, D.; Iliopoulou, A.; Irakleous-Palaiologou, E.; Gatidou, G.; Aloupi, M.; Antonopoulou, P.; Fountoulakis, M.S.; Stasinakis, A.S. Municipal wastewater treatment by combining in series microalgae Chlorella sorokiniana and macrophyte Lemna minor: Preliminary results. J. Clean. Prod. 2020, 271, 122704. [CrossRef]

46. Robles, Á.; Capson-Tojo, G.; Gales, A.; Viruela, A.; Sialve, B.; Seco, A.; Steyer, J.-P.; Ferrer, J. Performance of a membrane-coupled high-rate algal pond for urban wastewater treatment at demonstration scale. Bioresour. Technol. 2020, 301, 122672. [CrossRef] [PubMed]

47. Arashiro, L.T.; Ferrer, I.; Rousseau, D.P.L.; Van Hulle, S.W.H.; Garfí, M. The effect of primary treatment of wastewater in high rate algal pond systems: Biomass and bioenergy recovery. Bioresour. Technol. 2019, 280, 27-36. [CrossRef]

48. Ferro, L.; Colombo, M.; Posadas, E.; Funk, C.; Muñoz, R. Elucidating the symbiotic interactions between a locally isolated microalga Chlorella vulgaris and its co-occurring bacterium Rhizobium sp. in synthetic municipal wastewater. J. Appl. Phycol. 2019, 31, 2299-2310. [CrossRef]

49. Sforza, E.; Pastore, M.; Spagni, A.; Bertucco, A. Microalgae-bacteria gas exchange in wastewater: How mixotrophy may reduce the oxygen supply for bacteria. Environ. Sci. Pollut. Res. 2018, 25, 28004-28014. [CrossRef] [PubMed]

50. Arbib, Z.; Ruiz, J.; Álvarez-Díaz, P.; Garrido-Pérez, C.; Perales, J.A. Capability of different microalgae species for phytoremediation processes: Wastewater tertiary treatment, $\mathrm{CO}_{2}$ bio-fixation and low cost biofuels production. Water Res. 2014, 49, 465-474. [CrossRef]

51. Álvarez-Díaz, P.D.; Ruiz, J.; Arbib, Z.; Barragán, J.; Garrido-Pérez, M.C.; Perales, J.A. Freshwater microalgae selection for simultaneous wastewater nutrient removal and lipid production. Algal Res. 2017, 24, 477-485. [CrossRef]

52. Marazzi, F.; Bellucci, M.; Rossi, S.; Fornaroli, R.; Ficara, E.; Mezzanotte, V. Outdoor pilot trial integrating a sidestream microalgae process for the treatment of centrate under non optimal climate conditions. Algal Res. 2019, 39, 101430. [CrossRef]

53. Şirin, S.; Sillanpää, M. Cultivating and harvesting of marine alga Nannochloropsis oculata in local municipal wastewater for biodiesel. Bioresour. Technol. 2015, 191, 79-87. [CrossRef] [PubMed]

54. Caporgno, M.P.; Taleb, A.; Olkiewicz, M.; Font, J.; Pruvost, J.; Legrand, J.; Bengoa, C. Microalgae cultivation in urban wastewater: Nutrient removal and biomass production for biodiesel and methane. Algal Res. 2015, 10, 232-239. [CrossRef]

55. Nzayisenga, J.C.; Eriksson, K.; Sellstedt, A. Mixotrophic and heterotrophic production of lipids and carbohydrates by a locally isolated microalga using wastewater as a growth medium. Bioresour. Technol. 2018, 257, 260-265. [CrossRef]

56. Tao, R.; Kinnunen, V.; Praveenkumar, R.; Lakaniemi, A.-M.; Rintala, J.A. Comparison of Scenedesmus acuminatus and Chlorella vulgaris cultivation in liquid digestates from anaerobic digestion of pulp and paper industry and municipal wastewater treatment sludge. J. Appl. Phycol. 2017, 29, 2845-2856. [CrossRef]

57. Hultberg, M.; Olsson, L.E.; Birgersson, G.; Gustafsson, S.; Sievertsson, B. Microalgal growth in municipal wastewater treated in an anaerobic moving bed biofilm reactor. Bioresour. Technol. 2016, 207, 19-23. [CrossRef]

58. Evans, L.; Hennige, S.J.; Willoughby, N.; Adeloye, A.J.; Skroblin, M.; Gutierrez, T. Effect of organic carbon enrichment on the treatment efficiency of primary settled wastewater by Chlorella vulgaris. Algal Res. 2017, 24, 368-377. [CrossRef]

59. Hodaifa, G.; Sánchez, S.; Martínez, M.E.; Órpez, R. Biomass production of Scenedesmus obliquus from mixtures of urban and olive-oil mill wastewaters used as culture medium. Appl. Energy 2013, 104, 345-352. [CrossRef]

60. Mendez, L.; Sialve, B.; Tomás-Pejó, E.; Ballesteros, M.; Steyer, J.P.; González-Fernández, C. Comparison of Chlorella vulgaris and cyanobacterial biomass: Cultivation in urban wastewater and methane production. Bioprocess Biosyst. Eng. 2016, 39, 703-712. [CrossRef] [PubMed]

61. Abdel-Raouf, N.; Al-Homaidan, A.A.; Ibraheem, I.B.M. Microalgae and wastewater treatment. Saudi J. Biol. Sci. 2012, 19, 257-275. [CrossRef] [PubMed]

62. Sun, J.; Xiong, X.; Wang, M.; Du, H.; Li, J.; Zhou, D.; Zuo, J. Microalgae biodiesel production in China: A preliminary economic analysis. Renew. Sustain. Energy Rev. 2019, 104, 296-306. [CrossRef]

63. Ledda, C.; Romero Villegas, G.I.; Adani, F.; Acién Fernández, F.G.; Molina Grima, E. Utilization of centrate from wastewater treatment for the outdoor production of Nannochloropsis gaditana biomass at pilot-scale. Algal Res. 2015, 12, 17-25. [CrossRef]

64. Schulze, P.S.C.; Carvalho, C.F.M.; Pereira, H.; Gangadhar, K.N.; Schüler, L.M.; Santos, T.F.; Varela, J.C.S.; Barreira, L. Urban wastewater treatment by Tetraselmis sp. CTP4 (Chlorophyta). Bioresour. Technol. 2017, 223, 175-183. [CrossRef] [PubMed] 
65. Arbib, Z.; Ruiz, J.; Alvarez, P.; Garrido, C.; Barragan, J.; Perales, J.A. Chlorella stigmatophora for Urban Wastewater Nutrient Removal and $\mathrm{CO}_{2}$ Abatement. Int. J. Phytoremediat. 2012, 14, 714-725. [CrossRef] [PubMed]

66. Dębowski, M.; Szwaja, S.; Zieliński, M.; Kisielewska, M.; Stańczyk-Mazanek, E. The Influence of Anaerobic Digestion Effluents (ADEs) Used as the Nutrient Sources for Chlorella sp. Cultivation on Fermentative Biogas Production. Waste Biomass Valoriz. 2017, 8, 1153-1161. [CrossRef]

67. Uggetti, E.; Sialve, B.; Hamelin, J.; Bonnafous, A.; Steyer, J.-P. $\mathrm{CO}_{2}$ addition to increase biomass production and control microalgae species in high rate algal ponds treating wastewater. J. CO2 Util. 2018, 28, 292-298. [CrossRef]

68. Arbib, Z.; Ruiz, J.; Álvarez-Díaz, P.; Garrido-Pérez, C.; Barragan, J.; Perales, J.A. Effect of pH control by means of flue gas addition on three different photo-bioreactors treating urban wastewater in long-term operation. Ecol. Eng. 2013, 57, 226-235. [CrossRef]

69. Iasimone, F.; De Felice, V.; Panico, A.; Pirozzi, F. Experimental study for the reduction of $\mathrm{CO}_{2}$ emissions in wastewater treatment plant using microalgal cultivation. J. CO2 Util. 2017, 22, 1-8. [CrossRef]

70. Andersson, V.; Broberg Viklund, S.; Hackl, R.; Karlsson, M.; Berntsson, T. Algae-based biofuel production as part of an industrial cluster. Biomass Bioenergy 2014, 71, 113-124. [CrossRef]

71. Foladori, P.; Petrini, S.; Andreottola, G. How suspended solids concentration affects nitrification rate in microalgal-bacterial photobioreactors without external aeration. Heliyon 2020, 6, e03088. [CrossRef]

72. Galès, A.; Bonnafous, A.; Carré, C.; Jauzein, V.; Lanouguère, E.; Le Floc'h, E.; Pinoit, J.; Poullain, C.; Roques, C.; Sialve, B.; et al. Importance of ecological interactions during wastewater treatment using High Rate Algal Ponds under different temperate climates. Algal Res. 2019, 40, 101508. [CrossRef]

73. Koreiviene, J.; Valčiukas, R.; Karosiene, J.; Baltrenas, P. Testing of Chlorella/Scenedesmus microalgae consortia for remediation of wastewater, $\mathrm{CO}_{2}$ mitigation and algae biomass feasibility for lipid production. J. Environ. Eng. Landsc. Manag. 2014, 22, 105-114. [CrossRef]

74. Ras, M.; Steyer, J.-P.; Bernard, O. Temperature effect on microalgae: A crucial factor for outdoor production. Rev. Environ. Sci. Bio/Technol. 2013, 12, 153-164. [CrossRef]

75. Salvucci, M.E.; Crafts-Brandner, S.J. Relationship between the Heat Tolerance of Photosynthesis and the Thermal Stability of Rubisco Activase in Plants from Contrasting Thermal Environments. Plant Physiol. 2004, 134, 1460-1470. [CrossRef]

76. Iasimone, F.; Panico, A.; De Felice, V.; Fantasma, F.; Iorizzi, M.; Pirozzi, F. Effect of light intensity and nutrients supply on microalgae cultivated in urban wastewater: Biomass production, lipids accumulation and settleability characteristics. J. Environ. Manag. 2018, 223, 1078-1085. [CrossRef] [PubMed]

77. Khiewwijit, R.; Rijnaarts, H.; Temmink, H.; Keesman, K.J. Glocal assessment of integrated wastewater treatment and recovery concepts using partial nitritation/Anammox and microalgae for environmental impacts. Sci. Total Environ. 2018, 628-629, 74-84. [CrossRef] [PubMed]

78. Ferro, L.; Gentili, F.G.; Funk, C. Isolation and characterization of microalgal strains for biomass production and wastewater reclamation in Northern Sweden. Algal Res. 2018, 32, 44-53. [CrossRef]

79. Di Termini, I.; Prassone, A.; Cattaneo, C.; Rovatti, M. On the nitrogen and phosphorus removal in algal photobioreactors. Ecol. Eng. 2011, 37, 976-980. [CrossRef]

80. Nzayisenga, J.C.; Niemi, C.; Ferro, L.; Gorzsas, A.; Gentili, F.G.; Funk, C.; Sellstedt, A. Screening suitability of northern hemisphere algal strains for heterotrophic cultivation and fatty acid methyl ester production. Molecules 2020, 25, 2107. [CrossRef]

81. Samorì, G.; Samorì, C.; Pistocchi, R. Nutrient removal efficiency and physiological responses of Desmodesmus communis at different HRTs and nutrient stress condition using different sources of urban wastewater effluents. Appl. Biochem. Biotechnol. 2014, 173, 74-89. [CrossRef] [PubMed]

82. Wang, Y.; Ho, S.H.; Cheng, C.L.; Guo, W.Q.; Nagarajan, D.; Ren, N.Q.; Lee, D.J.; Chang, J.S. Perspectives on the feasibility of using microalgae for industrial wastewater treatment. Bioresour. Technol. 2016, 222, 485-497. [CrossRef] [PubMed]

83. Petrie, B.; Barden, R.; Kasprzyk-Hordern, B. A review on emerging contaminants in wastewaters and the environment: Current knowledge, understudied areas and recommendations for future monitoring. Water Res. 2015, 72, 3-27. [CrossRef]

84. Encarnação, T.; Palito, C.; Pais, A.A.C.C.; Valente, A.J.M.; Burrows, H.D. Removal of Pharmaceuticals from Water by Free and Imobilised Microalgae. Molecules 2020, 25, 3639. [CrossRef] [PubMed]

85. Chong, A.M.Y.; Wong, Y.S.; Tam, N.F.Y. Performance of different microalgal species in removing nickel and zinc from industrial wastewater. Chemosphere 2000, 41, 251-257. [CrossRef]

86. Bellucci, M.; Marazzi, F.; Naddeo, L.S.; Piergiacomo, F.; Beneduce, L.; Ficara, E.; Mezzanotte, V. Disinfection and nutrient removal in laboratory-scale photobioreactors for wastewater tertiary treatment. J. Chem. Technol. Biotechnol. 2020, 95, 959-966. [CrossRef]

87. Henkanatte-Gedera, S.M.; Selvaratnam, T.; Caskan, N.; Nirmalakhandan, N.; Van Voorhies, W.; Lammers, P.J. Algal-based, single-step treatment of urban wastewaters. Bioresour. Technol. 2015, 189, 273-278. [CrossRef]

88. Sforza, E.; Pastore, M.; Santeufemia Sanchez, S.; Bertucco, A. Bioaugmentation as a strategy to enhance nutrient removal: Symbiosis between Chlorella protothecoides and Brevundimonas Diminuta. Bioresour. Technol. Rep. 2018, 4, 153-158. [CrossRef]

89. Kohlheb, N.; van Afferden, M.; Lara, E.; Arbib, Z.; Conthe, M.; Poitzsch, C.; Marquardt, T.; Becker, M.-Y. Assessing the life-cycle sustainability of algae and bacteria-based wastewater treatment systems: High-rate algae pond and sequencing batch reactor. $J$. Environ. Manag. 2020, 264, 110459. [CrossRef] 
90. Pastore, M.; Sforza, E. Exploiting symbiotic interactions between Chlorella protothecoides and Brevundimonas diminuta for an efficient single-step urban wastewater treatment. Water Sci. Technol. 2018, 78, 216-224. [CrossRef] [PubMed]

91. Petrini, S.; Foladori, P.; Beghini, F.; Armanini, F.; Segata, N.; Andreottola, G. How inoculation affects the development and the performances of microalgal-bacterial consortia treating real municipal wastewater. J. Environ. Manag. 2020, 263 , 110427. [CrossRef] [PubMed]

92. Krustok, I.; Odlare, M.; Truu, J.; Nehrenheim, E. Inhibition of nitrification in municipal wastewater-treating photobioreactors: Effect on algal growth and nutrient uptake. Bioresour. Technol. 2016, 202, 238-243. [CrossRef]

93. Henkanatte-Gedera, S.M.; Selvaratnam, T.; Karbakhshravari, M.; Myint, M.; Nirmalakhandan, N.; Van Voorhies, W.; Lammers, P.J. Removal of dissolved organic carbon and nutrients from urban wastewaters by Galdieria sulphuraria: Laboratory to field scale demonstration. Algal Res. 2017, 24, 450-456. [CrossRef]

94. Sakurai, T.; Aoki, M.; Ju, X.; Ueda, T.; Nakamura, Y.; Fujiwara, S.; Umemura, T.; Tsuzuki, M.; Minoda, A. Profiling of lipid and glycogen accumulations under different growth conditions in the sulfothermophilic red alga Galdieria sulphuraria. Bioresour. Technol. 2016, 200, 861-866. [CrossRef]

95. Gross, W.; Schnarrenberger, C. Heterotrophic Growth of Two Strains of the Acido-Thermophilic Red Alga Galdieria sulphuraria. Plant Cell Physiol. 1995, 36, 633-638. [CrossRef]

96. Minoda, A.; Sawada, H.; Suzuki, S.; Miyashita, S.I.; Inagaki, K.; Yamamoto, T.; Tsuzuki, M. Recovery of rare earth elements from the sulfothermophilic red alga Galdieria sulphuraria using aqueous acid. Appl. Microbiol. Biotechnol. 2015, 99, 1513-1519. [CrossRef] [PubMed]

97. Selvaratnam, T.; Pegallapati, A.K.; Montelya, F.; Rodriguez, G.; Nirmalakhandan, N.; Van Voorhies, W.; Lammers, P.J. Evaluation of a thermo-tolerant acidophilic alga, Galdieria sulphuraria, for nutrient removal from urban wastewaters. Bioresour. Technol. 2014, 156, 395-399. [CrossRef]

98. Oswald, W.J. My sixty years in applied algology. J. Appl. Phycol. 2003, 15, 99-106. [CrossRef]

99. Ruiz, J.; Álvarez, P.; Arbib, Z.; Garrido, C.; Barragán, J.; Perales, J.A. Effect of nitrogen and phosphorus concentration on their removal kinetic in treated urban wastewater by Chlorella Vulgaris. Int. J. Phytoremediat. 2011, 13, 884-896. [CrossRef]

100. Catone, C.M.; Ripa, M.; Geremia, E.; Ulgiati, S. Bio-products from algae-based biorefinery on wastewater: A review. J. Environ. Manag. 2021, 293, 112792. [CrossRef] [PubMed]

101. Kudahettige, N.P.; Pickova, J.; Gentili, F.G. Stressing algae for biofuel production: Biomass and biochemical composition of Scenedesmus dimorphus and Selenastrum minutum grown in municipal untreated wastewater. Front. Energy Res. $2018,6,132$. [CrossRef]

102. Tsapekos, P.; Kougias, P.G.; Alvarado-Morales, M.; Kovalovszki, A.; Corbière, M.; Angelidaki, I. Energy recovery from wastewater microalgae through anaerobic digestion process: Methane potential, continuous reactor operation and modelling aspects. Biochem. Eng. J. 2018, 139, 1-7. [CrossRef]

103. Patel, S.K.S.; Kumar, P.; Mehariya, S.; Purohit, H.J.; Lee, J.K.; Kalia, V.C. Enhancement in hydrogen production by co-cultures of Bacillus and Enterobacter. Int. J. Hydrogen Energy 2014, 39, 14663-14668. [CrossRef]

104. Adarme-Vega, T.C.; Lim, D.K.Y.; Timmins, M.; Vernen, F.; Li, Y.; Schenk, P.M. Microalgal biofactories: A promising approach towards sustainable omega-3 fatty acid production. Microbial Cell Factories 2012, 11, 96. [CrossRef] [PubMed]

105. Maheswari, N.U.; Ahilandeswari, K. Production of bioplastic using Spirulina platensis and comparison with commercial plastic Res. Environ. Life Sci. 2011, 4, 133-136.

106. Slepetiene, A.; Volungevicius, J.; Jurgutis, L.; Liaudanskiene, I.; Amaleviciute-Volunge, K.; Slepetys, J.; Ceseviciene, J. The potential of digestate as a biofertilizer in eroded soils of Lithuania. Waste Manag. 2020, 102, 441-451. [CrossRef] [PubMed]

107. González, I.; Herrero, N.; Siles, J.Á.; Chica, A.F.; Ángeles Martín, M.; Izquierdo, C.G.; Gómez, J.M. Wastewater nutrient recovery using twin-layer microalgae technology for biofertilizer production. Water Sci. Technol. 2020, 82, 1044-1061. [CrossRef] [PubMed]

108. Ali, S.; Rizwan, M.; Qayyum, M.F.; Ok, Y.S.; Ibrahim, M.; Riaz, M.; Arif, M.S.; Hafeez, F.; Al-Wabel, M.I.; Shahzad, A.N. Biochar soil amendment on alleviation of drought and salt stress in plants: A critical review. Environ. Sci. Pollut. Res. 2017, 24, 12700-12712. [CrossRef]

109. Posadas, E.; Muñoz, R.; Guieysse, B. Integrating nutrient removal and solid management restricts the feasibility of algal biofuel generation via wastewater treatment. Algal Res. 2017, 22, 39-46. [CrossRef]

110. Gutiérrez, R.; Passos, F.; Ferrer, I.; Uggetti, E.; García, J. Harvesting microalgae from wastewater treatment systems with natural flocculants: Effect on biomass settling and biogas production. Algal Res. 2015, 9, 204-211. [CrossRef]

111. Gutiérrez, R.; Ferrer, I.; Uggetti, E.; Arnabat, C.; Salvadó, H.; García, J. Settling velocity distribution of microalgal biomass from urban wastewater treatment high rate algal ponds. Algal Res. 2016, 16, 409-417. [CrossRef]

112. Mennaa, F.Z.; Arbib, Z.; Perales, J.A. Urban wastewater treatment by seven species of microalgae and analgal bloom: Biomass production, $\mathrm{N}$ and P removal kinetics andharvestability. Water Res. 2015, 83, 42-51. [CrossRef] [PubMed]

113. Úbeda, B.; Gálvez, J.Á.; Michel, M.; Bartual, A. Microalgae cultivation in urban wastewater: Coelastrum cf. pseudomicroporum as a novel carotenoid source and a potential microalgae harvesting tool. Bioresour. Technol. 2017, 228, 210-217. [CrossRef]

114. Gutiérrez, R.; Ferrer, I.; González-Molina, A.; Salvadó, H.; García, J.; Uggetti, E. Microalgae recycling improves biomass recovery from wastewater treatment high rate algal ponds. Water Res. 2016, 106, 539-549. [CrossRef] 
115. Garbowski, T.; Charazińska, S.; Pulikowski, K.; Wiercik, P. Application of microalgae cultivated on pine bark for the treatment of municipal wastewater in cylindrical photobioreactors. Water Environ. J. 2020, 34, 949-959. [CrossRef]

116. Boelee, N.C.; Temmink, H.; Janssen, M.; Buisman, C.J.N.; Wijffels, R.H. Nitrogen and phosphorus removal from municipal wastewater effluent using microalgal biofilms. Water Res. 2011, 45, 5925-5933. [CrossRef] [PubMed]

117. Boelee, N.C.; Temmink, H.; Janssen, M.; Buisman, C.J.N.; Wijffels, R.H. Scenario analysis of nutrient removal from municipal wastewater by microalgal biofilms. Water 2012, 4, 460-473. [CrossRef] 